\title{
\#USGS
}

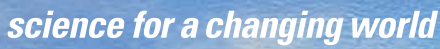

\section{Putting Down Roots in Earthquake Country Your Handbook for the San Francisco Bay Region}

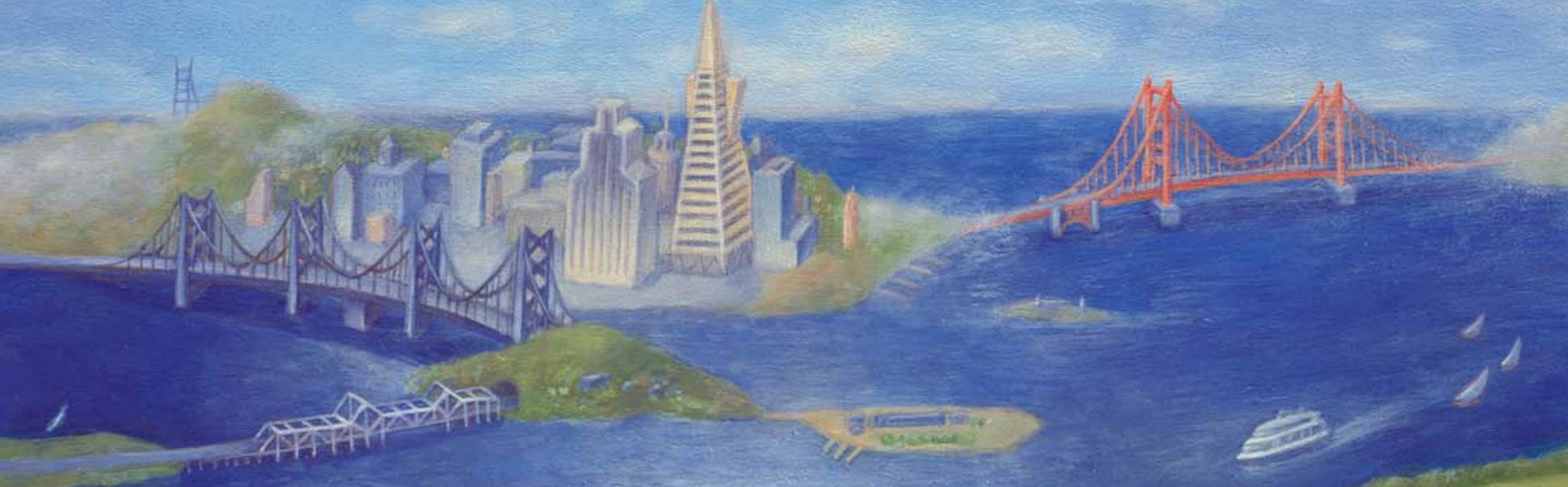

\section{Developed by: \\ American Red Cross, Bay Area Chapter}

General Information Product 15

Association of Bay Area Governments

California Earthquake Authority

California Geological Survey

Earthquake Engineering Research Institute

Governor's Office of Emergency Services

San Francisco Office of Emergency Services and Homeland Security

Southern California Earthquake Center

Structural Engineers Association of Northern California

University of California Berkeley

U.S. Department of Homeland Security, Federal Emergency Management Agency

U.S. Geological Survey

Major funding for printing provided by:

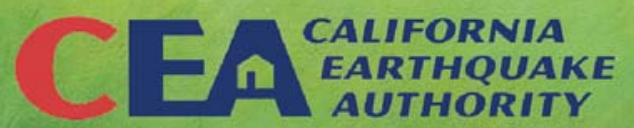

U.S. Department of the Interior

U.S. Geological Survey 
U.S. Department of the Interior

Gale A. Norton, Secretary

U.S. Geological Survey

P. Patrick Leahy, Acting Director

Any use of trade, product, or firm names in this publication is for descriptive purposes only and does not imply endorsement of the U.S. Government

United States Government Printing Office: 2005

Revised and reprinted, March 2006

Reprinted, June 2006

Revised and reprinted, May 2007

For additional copies please contact:

USGS Information Services

Box 25286

Denver, CO 80225

This report and any updates to it are available at: http://pubs.usgs.gov/gip/2005/15/

For more information about the USGS and its products: Telephone: 1-888-ASK-USGS (1-888-275-8747)

World Wide Web: http://www.usgs.gov/

Manuscript approved for publication, July 19, 2005

Cataloging-in-publication data are on file with the Library of Congress (URL http://www.loc.gov/).

This document is adapted from editions of "Putting Down Roots in Earthquake Country," written by Lucy Jones (U.S. Geological Survey) and Mark Benthien (Southern California Earthquake Center), published by the Southern California Earthquake Center (SCEC) in 1995, 2004, 2005 (see http://www.earthquakecountry. info/roots/).

Disclaimer: The suggestions and illustrations included in this document are intended to improve earthquake awareness and preparedness; however, they do not guarantee the safety of an individual or a structure. The contributors and sponsors of this handbook do not assume liability for any injury, death, property damage, or other effects of an earthquake.

CONTRIBUTORS: U.S. Geological Survey: Mary Lou Zoback, Steve Walter, Susan Garcia, Luke Blair, Marco Ticci, Howard Bundock, and Bob Simpson; American Red Cross: Harold Brooks, Helen Knudson, and Chris Kramer; Association of Bay Area Governments: Jeanne Perkins; California Earthquake Authority: Nancy Kincaid and Rolf Erickson; California Geological Survey: Keith Knudsen and Chris Wills; Earthquake Engineering Research Institute, Northern California Chapter: Fred Turner; Governor's Office of Emergency Services: Richard Eisner and Kathleen Bailey; QuakeHold!: Dean Reese and Jeff Primes; San Francisco Office of Emergency Services and Homeland Security: Doug Sandy; Southern California Earthquake Center: Mark Benthien and Robert de Groot; Structural Engineers Association of Northern California: Patricia Coate and Reinhard Ludke; University of California, Berkeley Seismological Laboratory: Lind Gee; U.S. Department of Homeland Security, Federal Emergency Management Agency: Jeffrey Lusk.

Text edited by James W. Hendley II and Peter H. Stauffer, USGS. Production, design, and illustration by Susan Mayfield, USGS.

Other illustrators: Jere Smith (front cover). Hans Bennewitz (FUEL Creative Group) (p. 19), Stephanie Langley (p. 4, 10, 25 26), Todd Connor (p. 20, 21, 27), and Judy Weathers (USGS) (p. 9, 23, 24)

\section{Contents}

\section{Why Should I Care? - The Bay Area Is Your Home}

All Bay Area residents live on an active plate boundary where earthquakes are frequent events! 4

History shows that damaging earthquakes have occurred throughout the Bay Area... 6

Most earthquake damage is caused by shaking... 8

Earthquakes also cause damage in other ways... 10

\section{Why Should I Prepare? - Big Quakes Will Affect You}

The disastrous 1989 Loma Prieta earthquake was not the "Big One"! 12

Many likely earthquake scenarios for the Bay Area will cause more damage than the Loma Prieta earthquake... 13

Your life could change unexpectedly in the next quake. Consider... 14

Where will your family be?

Will you have medical services?

Will you be able to get home?

Will you be able to stay in your home?

Can you live without the services you rely on?

How will your job be affected?

How will the American Red Cross help?

Your financial situation could be affected by a quake... $\quad \mathbf{1 6}$

Will you have money, food, and medicine?

Will you be able to recover financially?

Will your insurance cover your losses?

Does your small business have a recovery plan?

What will the Government do for you?

\section{What Should I Do? - Follow the Seven Steps to Earthquake Safety}

The seven steps to earthquake safety... 18

STEP 1-Identify potential hazards in your home and begin to fix them 20

STEP 2 - Create a disaster-preparedness plan 22

STEP 3-Prepare disaster kits 23

STEP 4-Identify your building's potential weaknesses and begin to fix them

STEP 5-Protect yourself during earthquake shaking DROP, COVER, AND HOLD ON $\mathbf{2 6}$

STEP 6 - After the quake, check for injuries and damage 27

STEP 7-When safe, continue to follow your disaster-preparedness plan

\section{What Else Should I Know?}

Earthquake information on the Web $\mathbf{3 0}$

Glossary 31 


\section{The Bay Area Is "Earthquake Country"}

$\mathbf{T}$

This handbook provides information about the threat posed by earthquakes in the San Francisco Bay region and explains how you can prepare for, survive, and recover from these inevitable events. If you live or work in the region, you need to know why you should be concerned with earthquakes, what you can expect during and after a quake, and what you need to do beforehand to be safe and reduce damage.

\section{Since the Great earthquake of 1906, much has been learned about earthquake hazards and vulnerabili- ties in the Bay Area:}

- We know why earthquakes occur here-The Bay Area straddles the boundary where two of the Earth's largest tectonic plates meet and slowly move past one another. When boundary faults break and the North American and Pacific Plates lurch past each other, quakes occur.

-We know large and damaging earthquakes are certain to occur in the future-At least eight faults in the Bay Area are capable of producing earthquakes of magnitude 6.7 or larger. Such quakes can kill and injure many people and cause substantial damage to buildings, roads, bridges, and utilities.

-We know how to reduce losses in future large earthquakes - Building codes have been improved, some older buildings strengthened, and bond measures approved to upgrade critical facilities. Some Bay Area residents have secured their homes to better withstand shaking, created emergency plans and disaster supply kits, and held home earthquake drills.

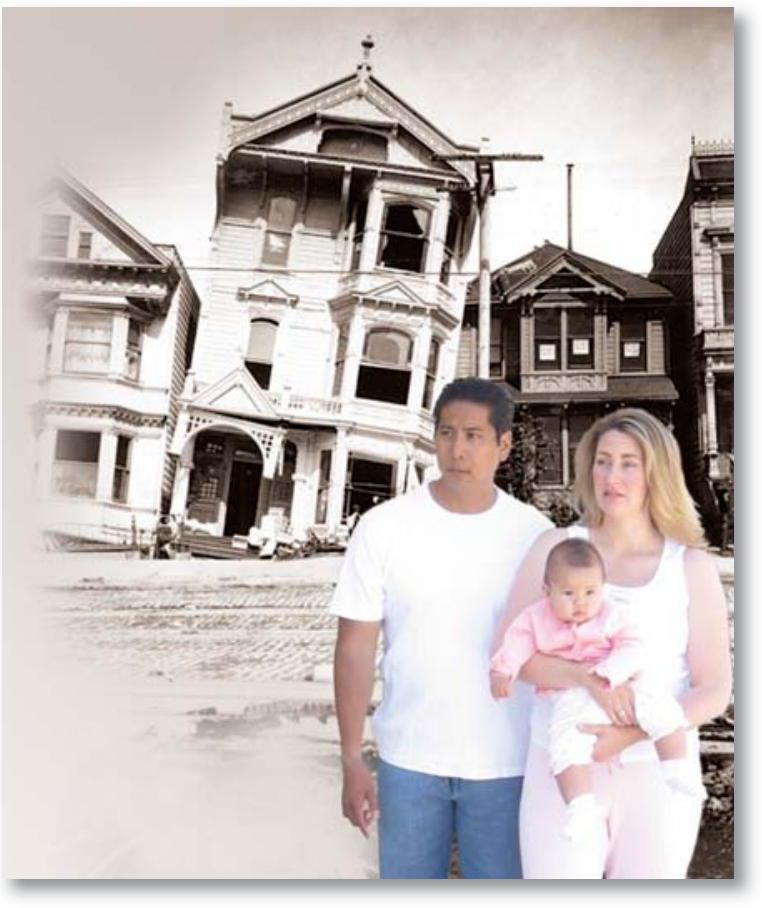

In the Great San Francisco earthquake of 1906, thousands of people died, and many homes were destroyed. The hazard remains in the Bay Area, and the homes of today's families are at risk! (USGS image)

\section{BUT we have not done enough to be prepared for the next large earthquake:}

- Fewer than $10 \%$ of households have disaster plansIf an earthquake occurred right now, where would you go to be safe? If you are at work and your children are at school when the earthquake occurs, how will you get back together?

- Fewer than $10 \%$ of homeowners have taken steps to retrofit their homes - Is your home bolted to its foundation? If you live in an older building, has it been retrofitted? Is your water heater strapped? Could unsecured furniture or objects fall and cause injury or damage?

- Fewer than $50 \%$ of households have disaster supply kits-You will likely be on your own in the hours and days following an earthquake. Are you prepared with water, food, first aid supplies, and medications? 


\section{All Bay Area Residents Live on an Active Plate Boundary Where Earthquakes Are Frequent Events!}

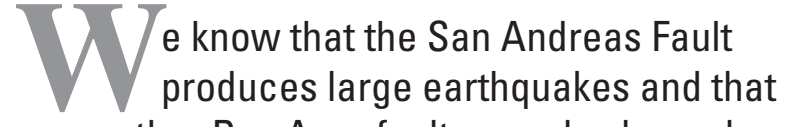
many other Bay Area faults are also hazardous. However, even knowing this, it can be difficult to understand how to use this information to make us safer in our daily lives. Should we care only if we live near the San Andreas Fault, or is every place in the Bay Area just as dangerous?

This eight-page section describes where earthquakes occur in northern California. It also explains how earthquakes will shake the ground and cause damage in other ways, such as liquefaction and landslides (see pages 8 through 11). Technical terms used throughout this book are explained in the Glossary (see page 31).

\section{JANUARY $1700 \mathrm{M} 9$}

In this computer simulation, tsunami waves are radiating outward after a magnitude (M) 9 earthquake that occurred on the Cascadia Subduction Zone offshore of northern California, Oregon, and Washington on January 26, 1700. This view shows the waves 4 hours after the quake. Colors indicate wave heights - red is highest. Along parts of the coast of the Pacific Northwest, 30-foot-high $(9 \mathrm{~m})$ waves rushed inland. Within 20 hours the tsunami did damage throughout the Pacific, and it is well documented in written records from Japan. (For more information go to http://pubs.usgs. gov/circ/c1187/. "Orphan tsunami" Web address: http://pubs.usgs.gov/pp/pp1707/.) 


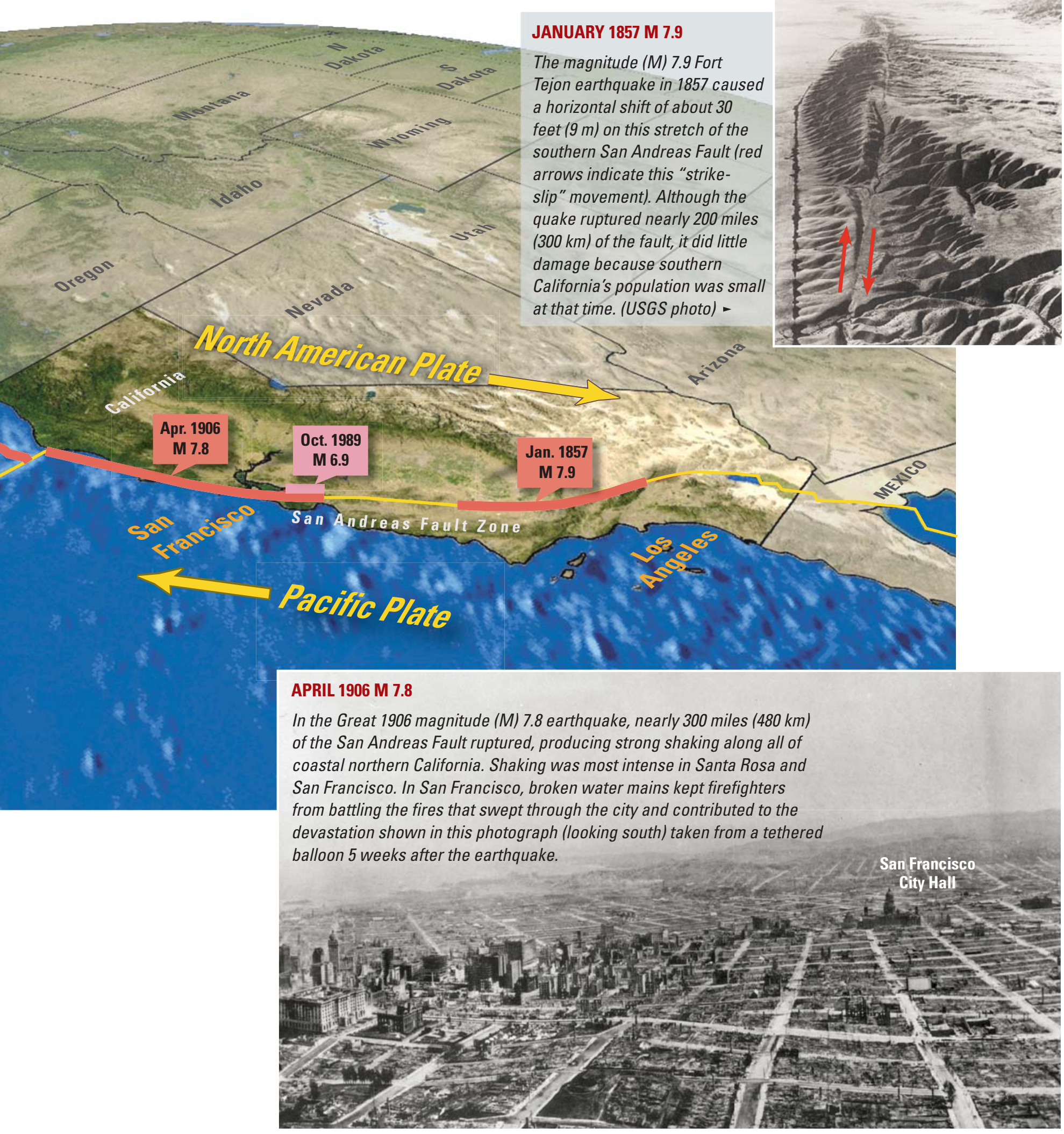

For more information go to:

http://neic.usgs.gov/neis/plate_tectonics/rift_man.html http://pubs.usgs.gov/gip/earthq3/ 


\section{History Shows That Damaging Earthquakes Have Occurred Throughout the Bay Area...}

\begin{abstract}
$\mathrm{n}$ the last half of the 1800 s, damaging

\section{occurred in the San Francisco Bay region \\ occurred in the San Francisco Bay region on average every 4 years. However, this changed in 1906:}

- On April 18, 1906, the San Andreas Fault ruptured violently over a length of 300 miles, causing damage from San Juan Bautista north as far as Eureka. This magnitude 7.8 earthquake-the "Great San Francisco earthquake" - relieved stresses on faults throughout the bay region.

- Because fault stresses were reduced, the rate of large quakes in the San Francisco Bay region dropped abruptly after the 1906 earthquake.

- The three-quarters of a century following the 1906 quake was a golden age for the bay region, in which urban areas and population expanded rapidly during a time of minimal quake activity.

- Although the level of seismic activity has not yet reached that of the late 1800 s, since 1906 stresses on Bay Area faults have been building up once again. The area can expect more frequent and stronger earthquakes in the future.

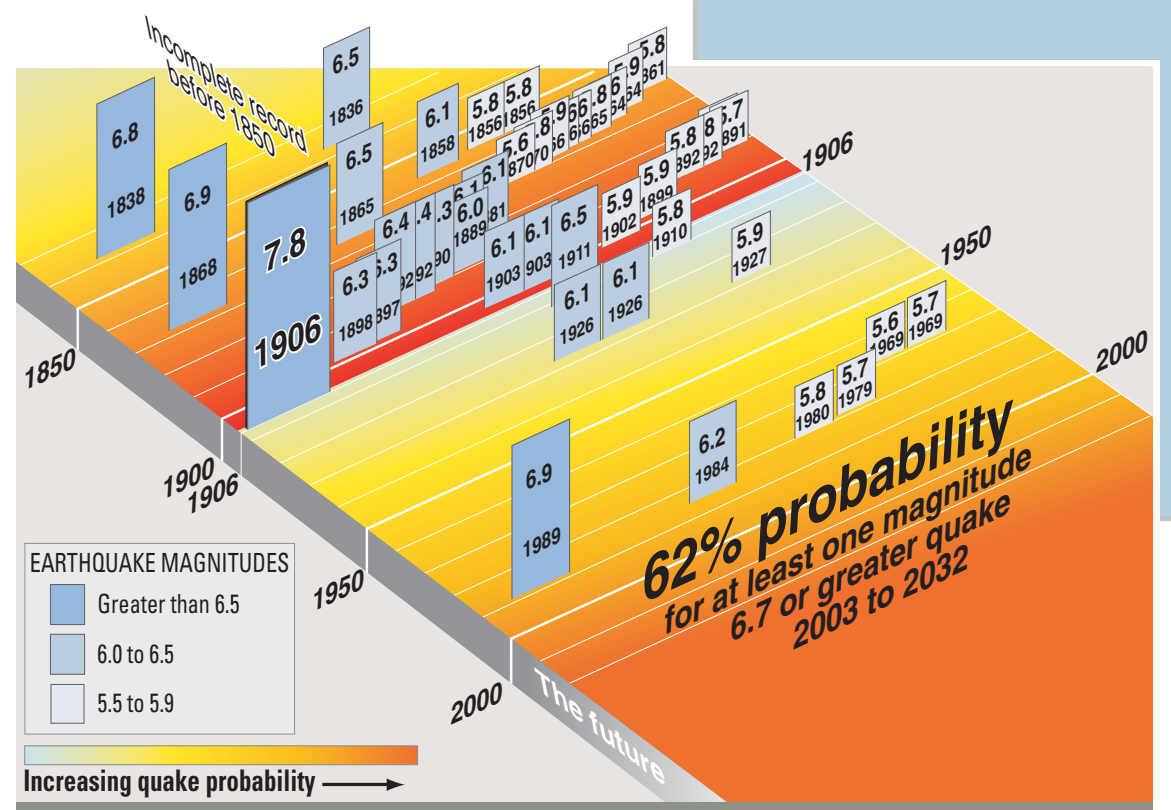

The Past and Future of Significant Bay Area Quakes

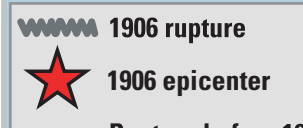

-.. Rupture before 1906Dotted where location uncertain

-.. Rupture after 1906Dotted where location uncertain Fault Urban areas in 1906

\section{Fault Rupture Lengths for Historical Quakes in the Bay Area} 1892 
Quakes can cause damage far from the fault rupture...

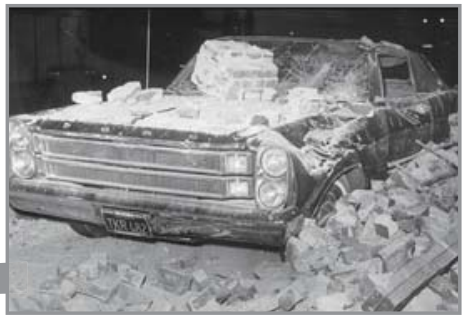

1969_Damage in Santa Rosa

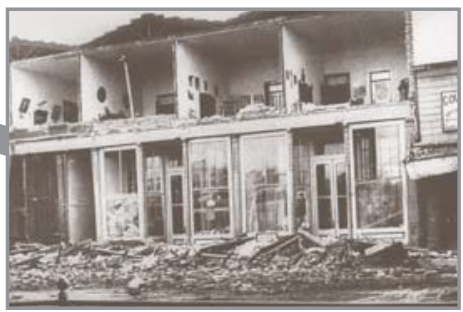

1906-Damage in Healdsburg

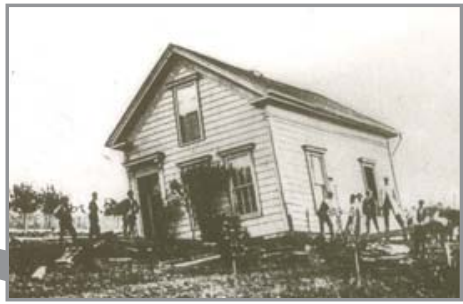

1868-Damage in Hayward

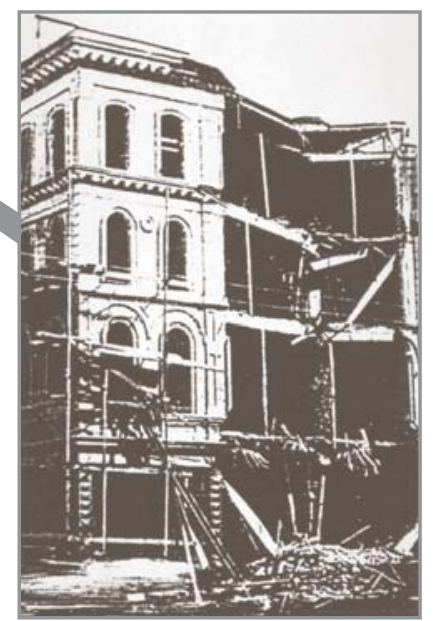

1865-Damage in San Francisco

(Historical photos of shaking damage courtesy National Information Service for Earthquake Engineering (NISEE), University of California, Berkeley.)

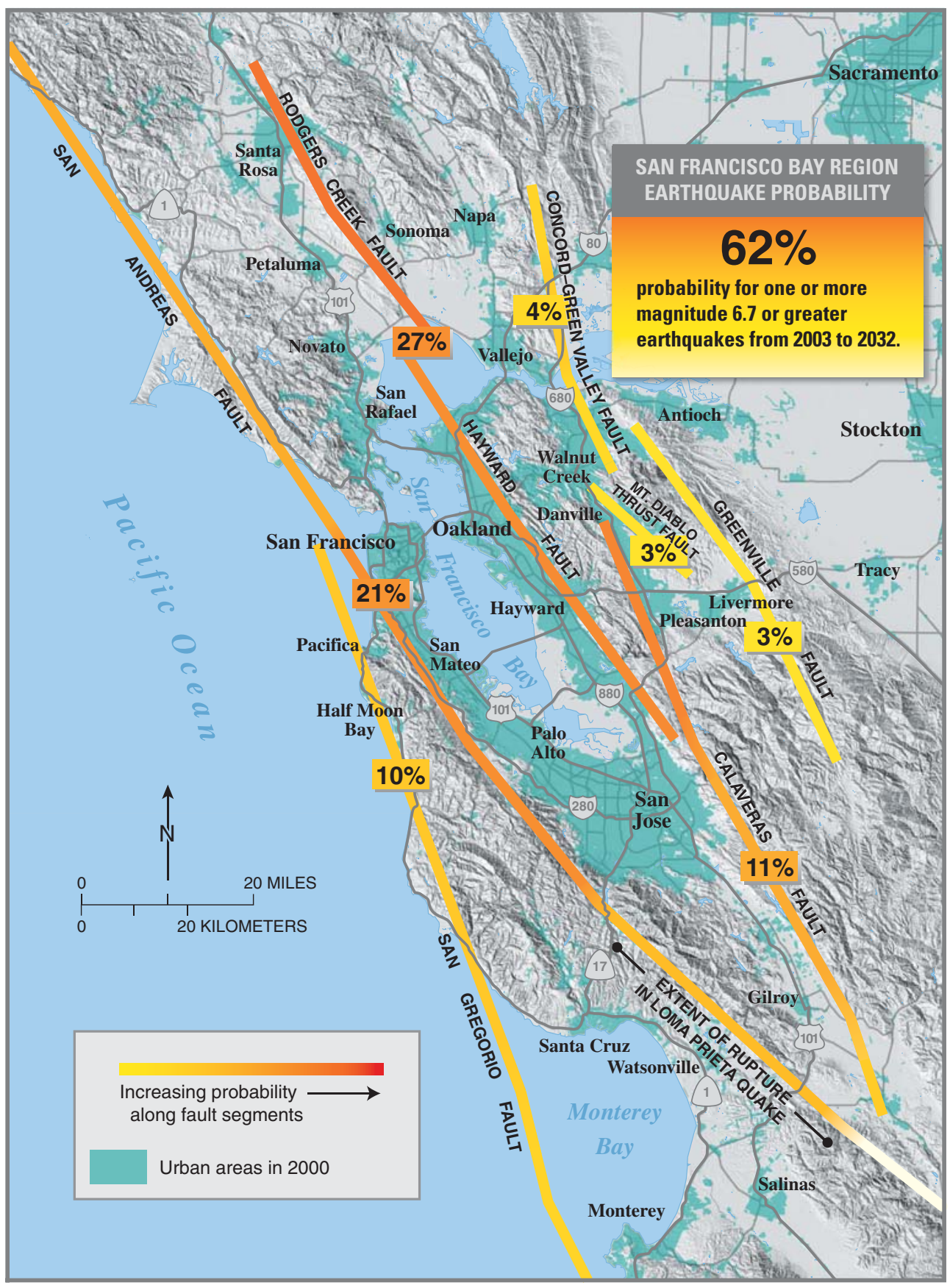

The threat of future quakes extends across the Bay Area...

There is a $62 \%$ probability that at least one earthquake of magnitude 6.7 or greater will occur on a known or unknown San Francisco Bay region fault before 2032. After a century of study by geologists, many faults have been mapped in the region, but not all faults are apparent at the surface-some quakes occur on previously unknown faults.

An example of a damaging quake on a previously unknown fault is the September 3, 2000, Yountville (Napa) earthquake. This magnitude 5.2 quake struck at 1:36 a.m., 10 miles northwest of Napa, rudely awakening many residents of the Bay Area. It injured 25 people, caused at least $\$ 10$ million in damage, and forced 70 people to seek shelter at Red Cross facilities. 


\section{Most Earthquake Damage Is Caused by Shaking...}

D amage in earthquakes is mainly from shaking. The intensity of shaking that a structure will experience during an earthquake is a function of three main factors:

(1) The magnitude of the earthquake-the larger the quake, the stronger the shaking.

(2) The distance from the fault that ruptured-the nearer you are to the fault, the greater the shaking.

(3) The type of ground materials beneath the structure-soft soils amplify the shaking; hard bedrock does not.

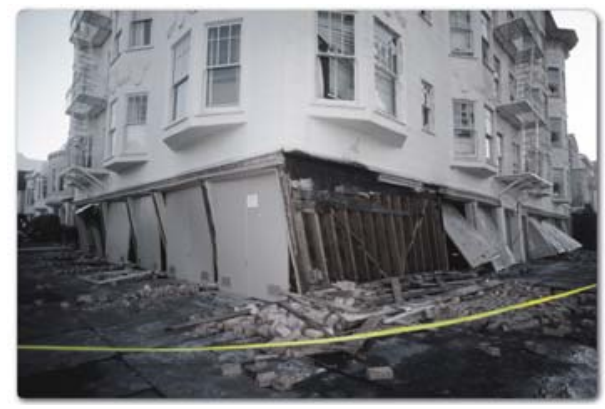

Buildings in the Marina District of San Francisco were badly damaged in the 1989 Loma Prieta earthquake. "Soft story" buildings, typically with parking on ground floor, like the one pictured here, are common throughout the Bay Area and are particularly at risk when exposed to strong shaking. (USGS photo)

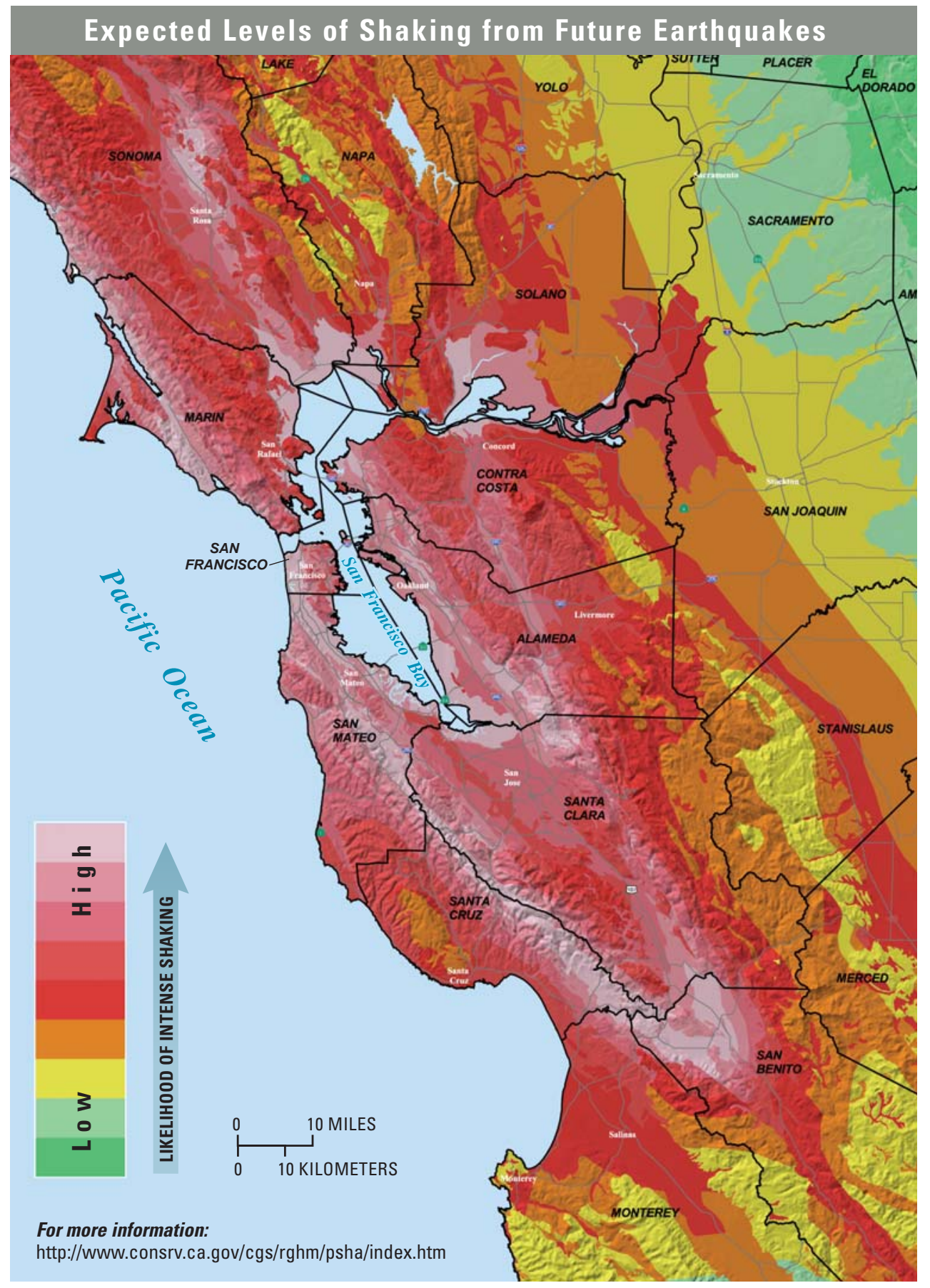

- On this map, bands of highest expected shaking generally follow major faults.

- Shaking levels are also influenced by the type of materials underlying an area-soft soils tend to amplify and prolong shaking, even at great distances from a quake.

- The worst soft soils in the Bay Area are the loose clays and filled areas bordering San Francisco Bay and the Sacramento-San Joaquin Delta.

- Deep soils in valleys shake more than bedrock in the hills-most urban development is in the valleys.

- Intense shaking can damage even strong, modern buildings and their contents. 


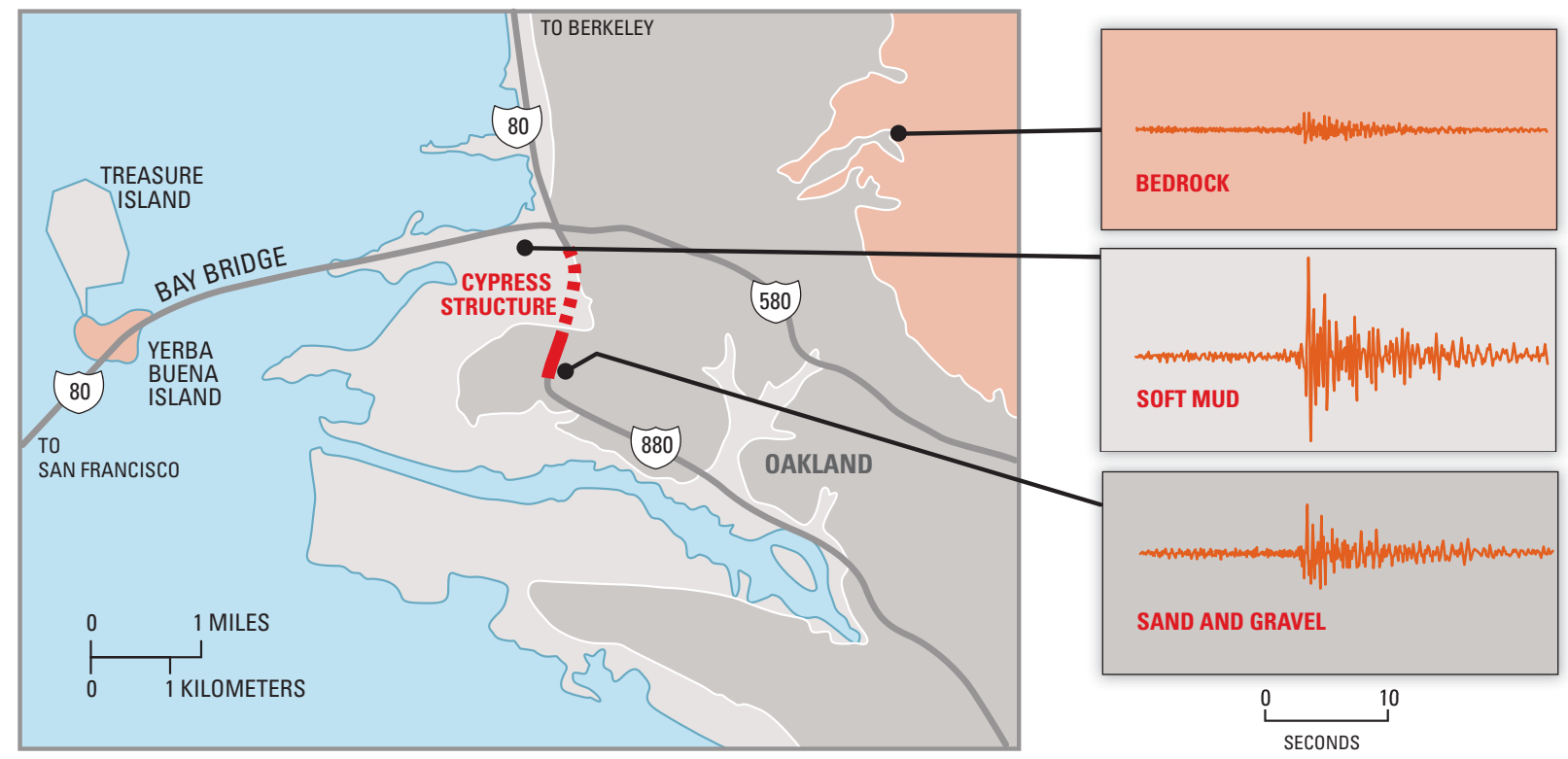

\section{Soft Soils Amplify Earthquake Shaking}

The Cypress freeway structure in Oakland was built in the 1950s, before the use of modern seismic-safety standards. Part of the structure standing on soft mud (dashed red line) collapsed in the 1989 magnitude 6.9 Loma Prieta earthquake, whose epicenter was nearly 60 miles $(100 \mathrm{~km})$ to the south. Adjacent parts of the structure (solid red) that were built on firmer ground remained standing. Seismograms (upper right) show that the shaking was especially severe in the soft
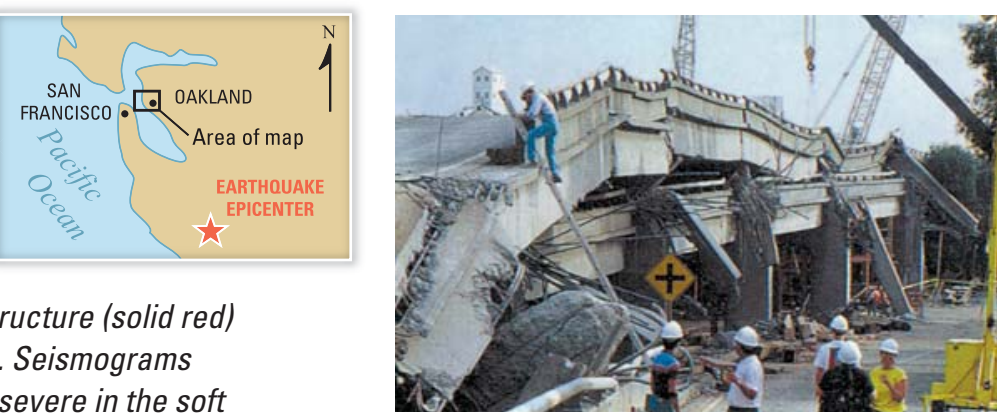
mud. (Photo by Lloyd S. Cluff, Pacific Gas \& Electric)

The Exposure of the Bay Area's Built Environment to Violent Earthquake Shaking-Many critical facilities in the Bay Area will likely experience damaging earthquake shaking in the next 30 years.

\begin{tabular}{|c|c|c|c|}
\hline & Types of facilities & $\begin{array}{c}\text { Number (or extent) of Bay Area } \\
\text { facilities with a high likelihood } \\
\text { of experiencing damaging } \\
\text { shaking in the next 30 years }\end{array}$ & $\begin{array}{c}\text { Percentage of total number of facilities } \\
\text { in the nine-county Bay Area }\end{array}$ \\
\hline Hospitals & 76 & 25 \\
\hline & Fire, Police, and Local Government & 2,970 & \\
\hline & Elementary Schools & 987 & \\
\hline & Intermediate or Middle Schools & 164 & \\
\hline & High Schools & 233 & \\
\hline & Bridges and Interchanges & 62 & \\
\hline
\end{tabular}




\section{Earthquakes Also Cause Damage in Other Ways...}

A

Ithough most earthquake damage is caused by shaking, other damaging effects of quakes can be just as devastating. For example, in the Great 1906 earthquake, the shaking damage in San Francisco was followed by fires that raged through the city almost uncontrolled, in part because water mains had broken in the quake. These and other destructive effects of quakes are discussed below.

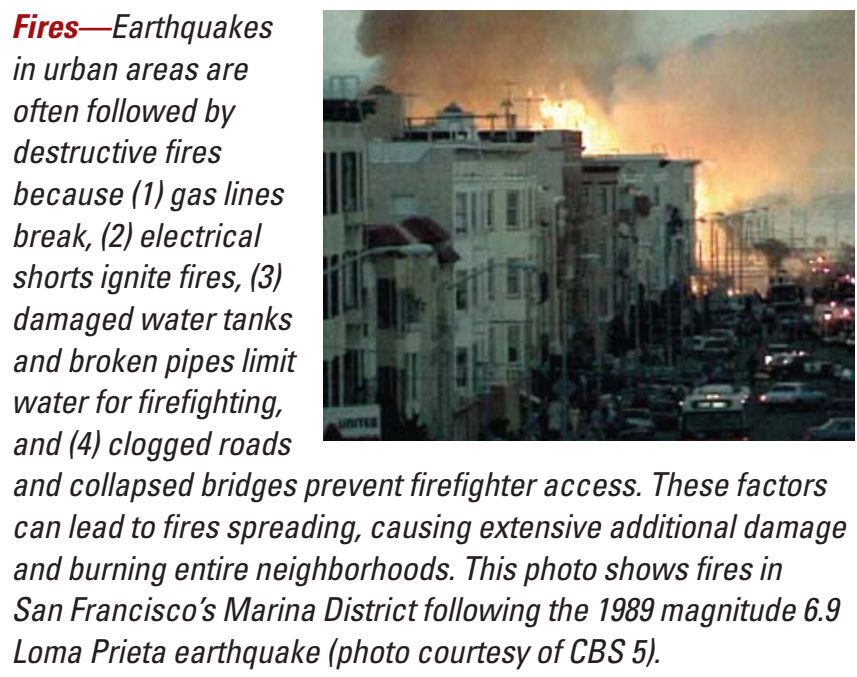

Don't be fooled!Myth number 2

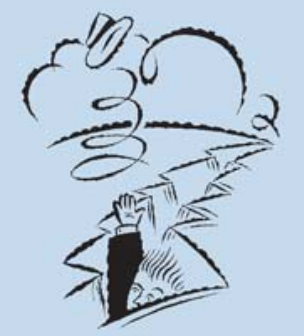

"AND THE EARTH OPENED..."

A popular literary device is a fault that opens during an earthquake and then closes to swallow up an inconvenient character. Unfortunately for principled writers, such "carnivorous" faults exist only in novels and B-movies.

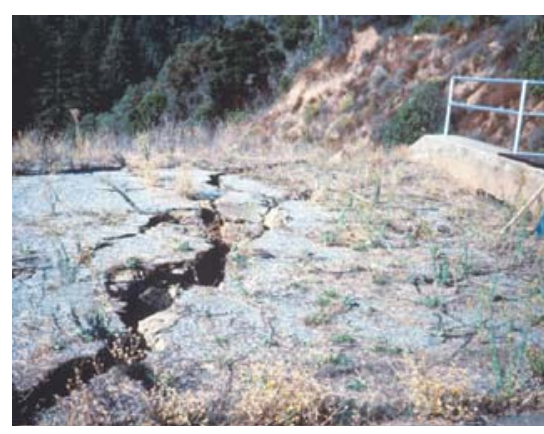

Dam failures_Earthquake shaking can cause dams to fail, potentially causing catastrophic downstream flooding and many dams provide hydroelectric power, which could be critically needed following a quake. Cracks in the top of this dam were caused by the 1989 magnitude 6.9 Loma Prieta earthquake (USGS photo). reduced water supplies. In addition,

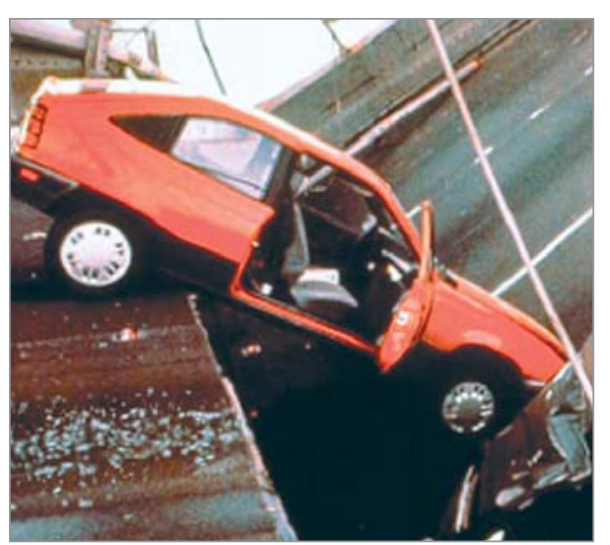

Damaged bridges, pipelines, powerlines, and roads-Earthquakes often damage roads, hindering rescue and recovery efforts and causing accidents. Water and sewer pipeline breaks result in water loss and can cause "sinkholes" that undermine roads and buildings. Damage to natural gas and electrical distribution systems can cause fires, as well as major service outages. This car crashed when a section of the eastern span of the San Francisco-Oakland Bay Bridge collapsed in the 1989 magnitude 6.9 Loma Prieta earthquake (Earthquake Engineering Research Institute photo).

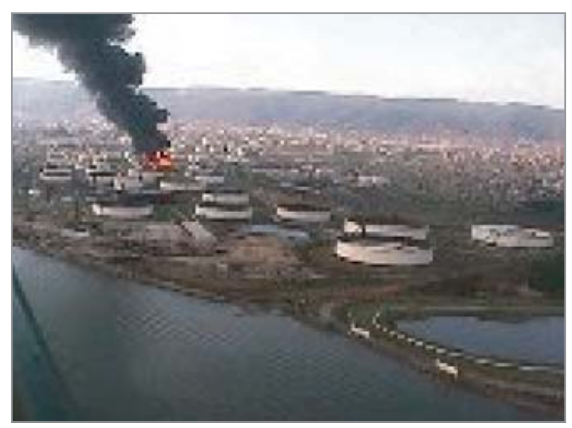

Hazardous material releases-Earthquake damage can cause releases of hazardous materials from refineries and other chemical storage and distribution systems, research and industrial laboratories, manufacturing plants, and railroad tank cars. Oil was released and caught fire when this storage facility was damaged by the 1999 magnitude 7.4 Izmit, Turkey, earthquake (photo by Kandilli Observatory and Earthquake Institute). 


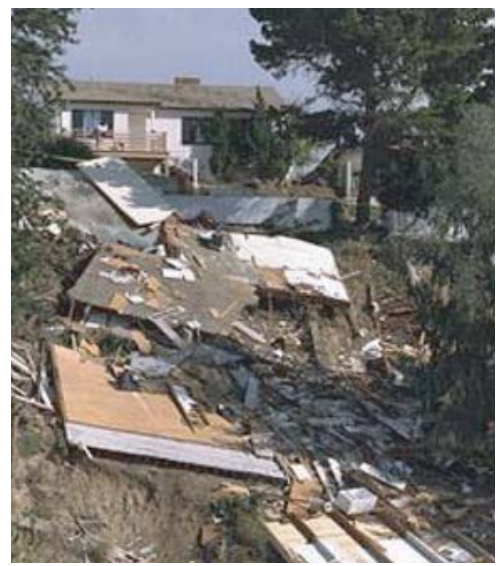

Landslides - Earthquakes can trigger landslides that damage roads, buildings, pipelines, and other infrastructure. Steeply sloping areas underlain by loose or soft rock are most susceptible to earthquake-induced landslides. This home was destroyed when the hillside beneath it gave way following the 1994 magnitude 6.7 Northridge earthquake (FEMA photo).

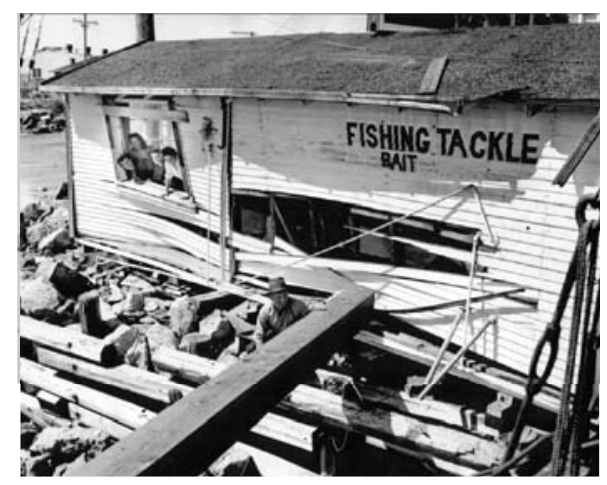

Tsunamis - Great earthquakes occurring anywhere in the Pacific Ocean may displace the ocean floor, generating tsunamis that could affect the California coast. Some coastal communities are designating Tsunami Hazard Zones and planning evacuation routes. Although the tsunami hazard in most of the Bay Area is low, coastal areas are still at risk. For example, this bait shop (Hazel's Fish Stand) in Half Moon Bay was ruined when it was hit by debris in the tsunami generated by the 1946 (magnitude 8) Alaska earthquake (photo copyright by MS \& $S B$ Collection).

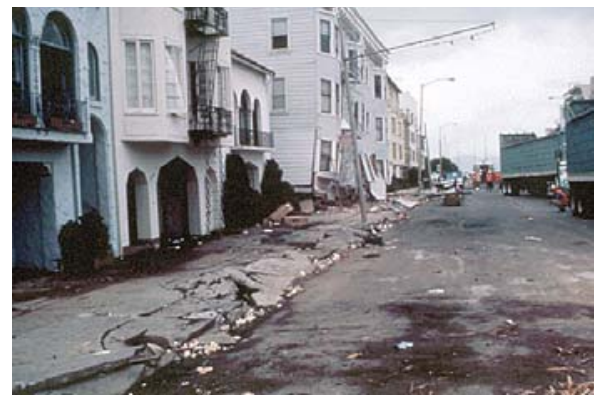

Liquefaction-Earthquake shaking can cause soils to behave like a liquid and lose their ability to support structures. Liquefaction often causes buried gas and water lines to break. The highest hazard is in lowlying areas where there are loose, sandy soils or poorly compacted artificial fill. This photo shows liquefaction-related damage in the Marina District of San Francisco following the 1989 magnitude 6.9 Loma Prieta earthquake (USGS photo).

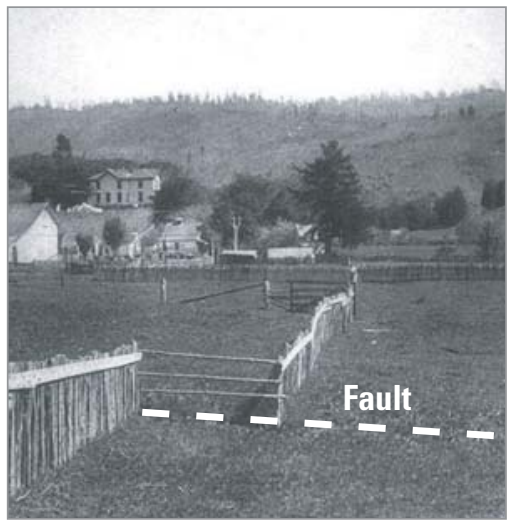

Surface rupture-Fault movements can break the ground surface, damaging buildings and other structures. This fence near Point Reyes was offset 8 feet ( $2.5 \mathrm{~m}$ ) when the San Andreas Fault moved in the Great (magnitude 7.8) 1906 earthquake (USGS photo).

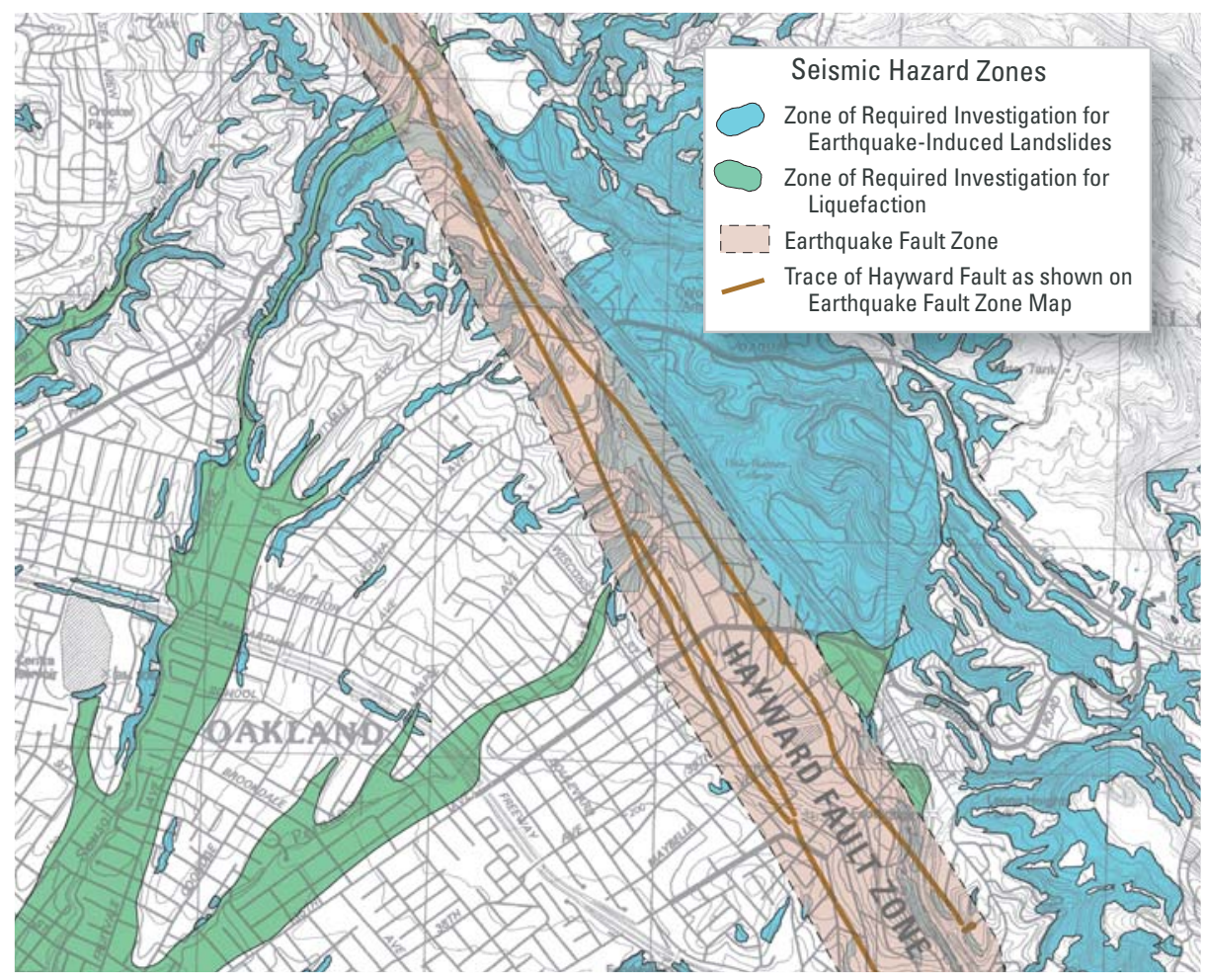

Map Showing Seismic Hazard Zones-This map of part of the Oakland area shows regulatory zones defined by the California Geological Survey (CGS) for three seismic hazards-earthquake-induced landsliding, liquefaction, and surface rupture. These zones indicate where the hazard may exist. Sites of proposed construction (new or remodel) within a zone must be investigated for the hazard. These maps are also used in real-estate transactions - disclosure is required if a property is within any of these hazard zones. CGS seismic hazard zone maps for the Bay Area are available at http://www.consrv.ca.gov/ cgs/geologic_hazards/regulatory_hazard_zones/index.htm. 


\section{The Disastrous 1989 Loma Prieta Earthquake Was Not the "Big One"!}

T he Loma Prieta earthquake released only $3 \%$ of the energy of the Great 1906 quake. Although it occurred in the Santa Cruz Mountains, far from the Bay Area's urban centers, it caused destruction not only in nearby Santa Cruz and Watsonville but also in San Francisco and Oakland:

- More than 60 people died, most in the collapse of the Cypress freeway structure in Oakland.

- About 16,000 homes and apartment units were so badly damaged that they could no longer be lived in. The American Red Cross operated 45 shelters housing more than 6,000 people, many of them for several months.

- The San Francisco-Oakland Bay Bridge was closed for more than a month because a portion of its eastern span collapsed. This closure and the collapse of the Cypress Freeway were the most dramatic of 142 road closures in the Bay Area.

- Direct physical damage to buildings and structures totaled $\$ 6$ billion; other related losses were an additional \$4 billion (losses in 1989 dollars).

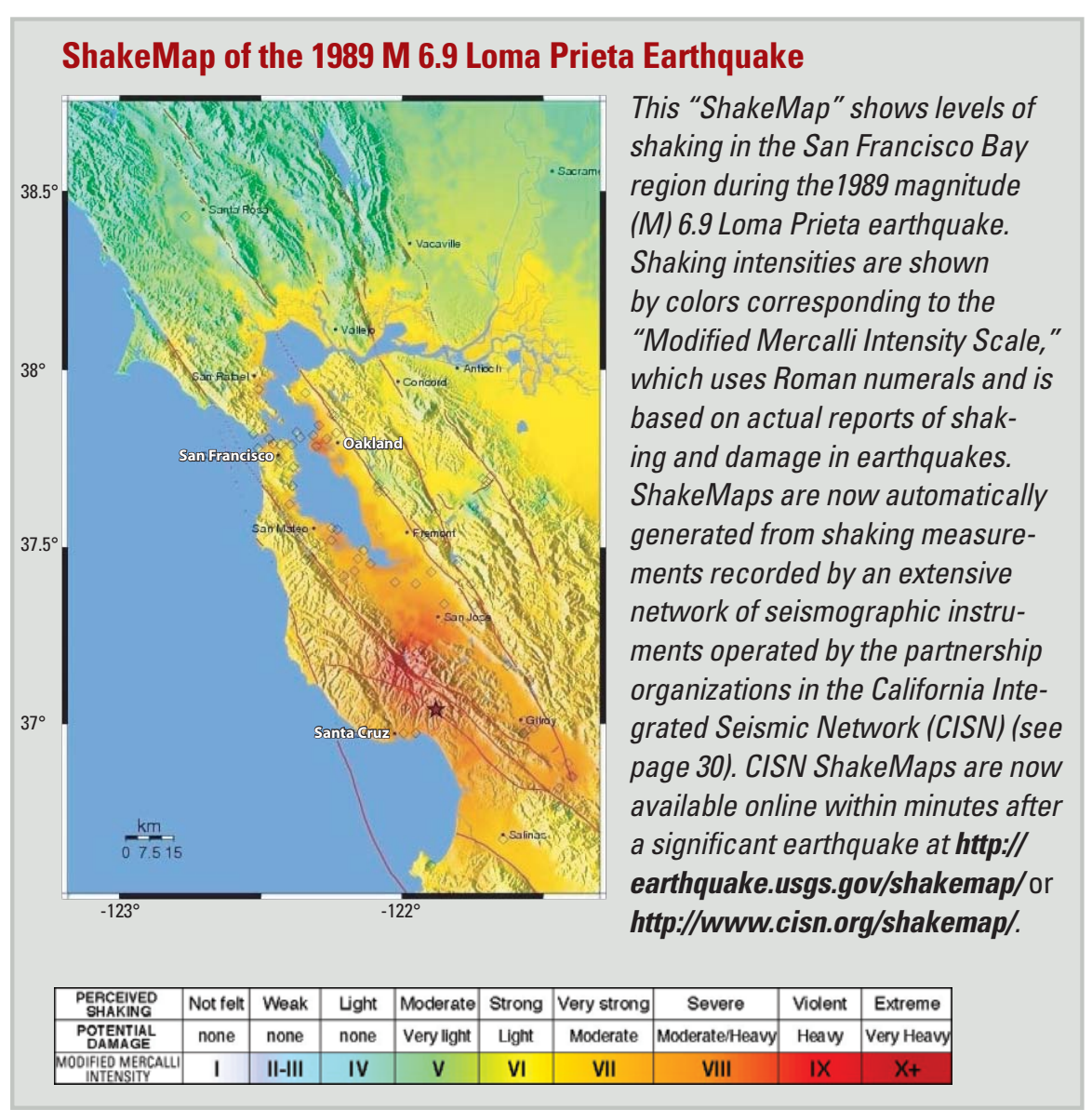

\section{How Do I Find Out the Expected Shaking in My Neighborhood?}

The Association of Bay Area Governments (ABAG) operates a Web site designed to provide this information in the form of earthquake-shaking hazard maps at http://quake.abag.ca.gov/. These maps show expected shaking intensities in the Bay Area for various earthquake scenarios, such as a quake on the Peninsula segment of the San Andreas Fault or the northern Hayward Fault. These maps can be "zoomed in" to display your neighborhood.

Other ABAG earthquake hazard maps show areas of liquefaction susceptibility, landslide hazards, potential fault ruptures, and tsunami inundation. ABAG even has maps for other natural hazards such as wildfires and flooding.

\section{Some words of caution:}

- Because these hazard maps are based on general information, they are reasonably accurate for a neighborhood, but much less accurate for a particular address.

- The maps in this booklet or on ABAG's Web site are based on probabilities, so actual earthquakes could produce different damage patterns.
ABAG Earthquake Shaking ScenarioSan Andreas Fault (Peninsula Segment ) Magnitude 7.2

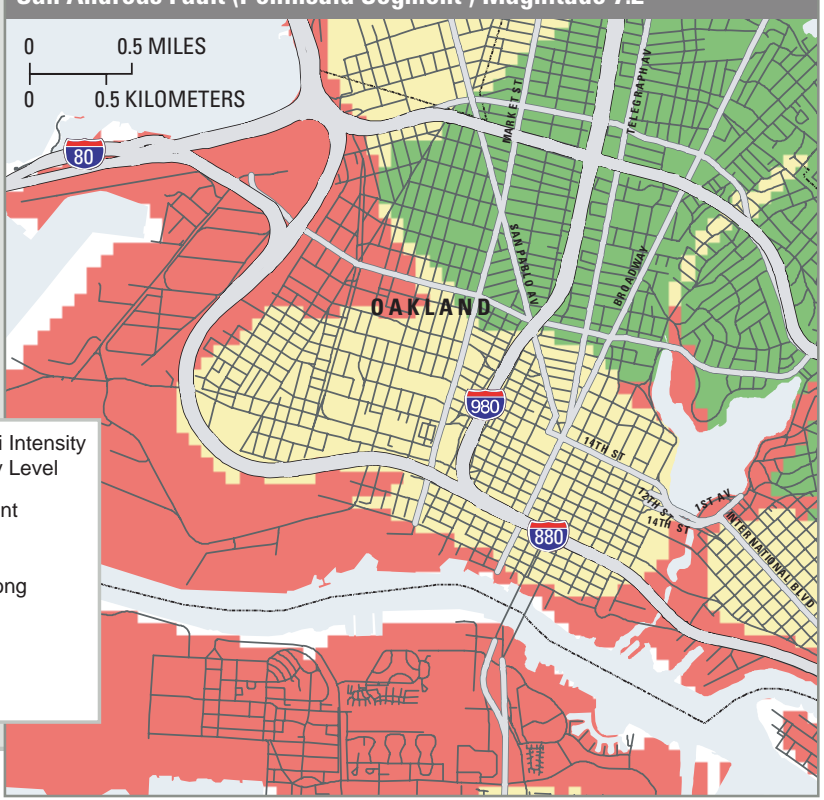

Modified Mercalli Intensity Shaking Severity Level

X-Very Violent IX-Violent VIII-VeryStrong VII-Strong VI-Moderate V-Light 


\section{Many Likely Earthquake Scenarios for the Bay Area Will Cause More Damage Than the Loma Prieta Earthquake...}

W hat if the Hayward Fault in the East Bay ruptured from San Pablo Bay to Fremont in an earthquake of magnitude 6.9, like Loma Prieta?

If this scenario earthquake for the Hayward Fault occurs, areas of soft soils along the margins of San Francisco Bay, particularly in the East Bay, are likely to experience intense shaking and liquefaction. These areas are heavily urbanized and may have devastation similar to or greater than that of the area around the Cypress freeway structure in Oakland in 1989, shown below.

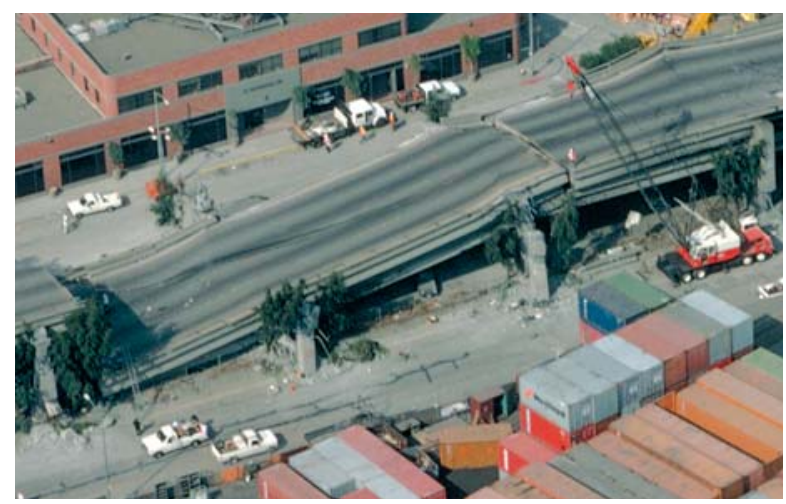

(USGS photo)

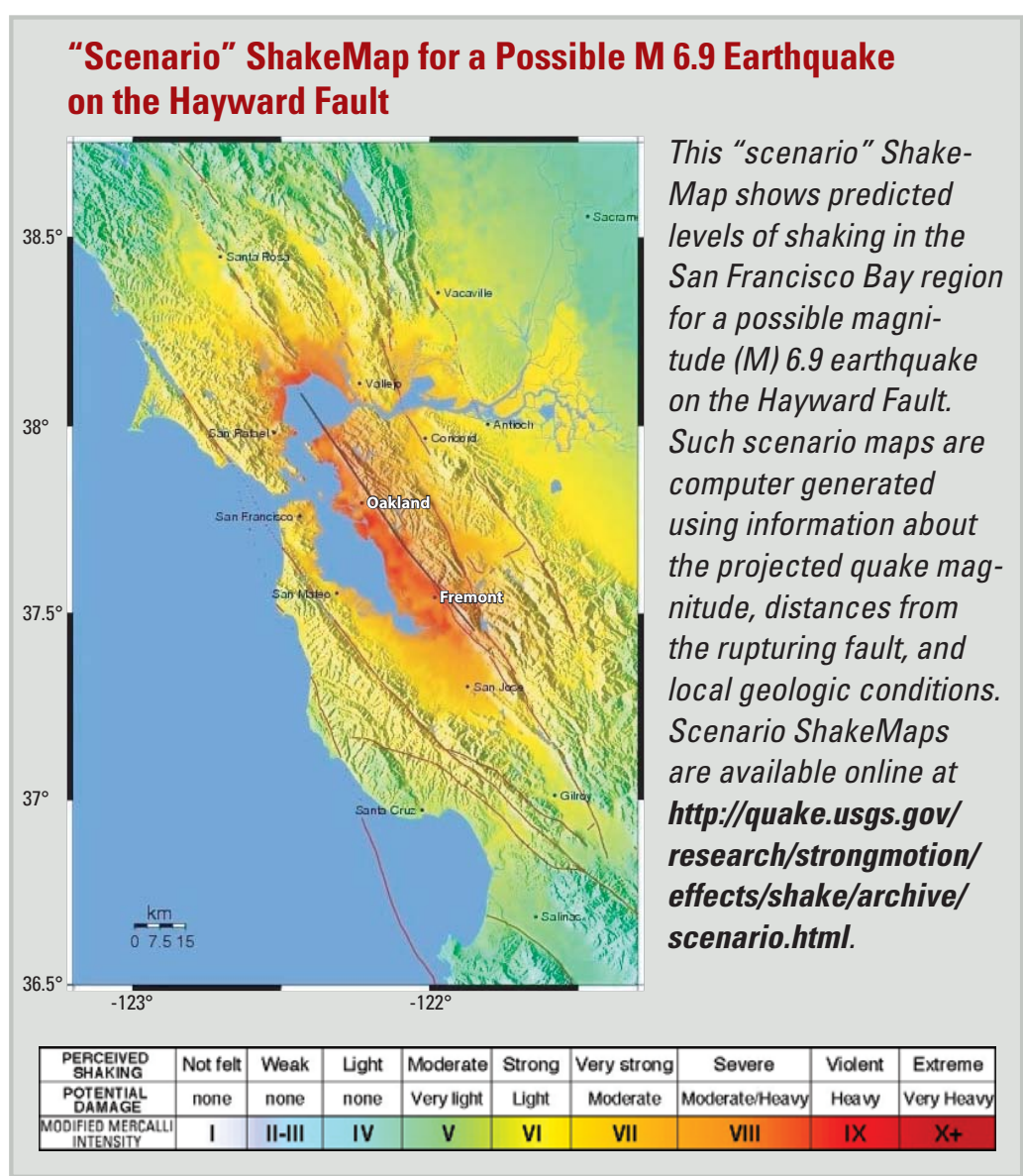

Projected Consequences and Implications for the Bay Area from a Magnitude 6.9 Earthquake on the Hayward Fault

\begin{tabular}{|c|c|c|c|}
\hline Facilities & Projected Losses & Who Is Taking Action? & What Can I Do To Prepare? \\
\hline Housing & $\begin{array}{l}\text { - } 80,000 \text { to } 160,000 \text { homes and } \\
\text { apartment units become } \\
\text { uninhabitable (10 times the } \\
\text { number in the Loma Prieta } \\
\text { quake). } \\
\text { - As many as } 300,000 \text { people are } \\
\text { forced from their homes. } \\
\text { - As many as } 150,000 \text { people } \\
\text { require public shelter. }\end{array}$ & $\begin{array}{l}\text { The American Red Cross, } \\
\text { cities, and counties } \\
\text { are planning for public } \\
\text { shelters. } \\
\text { Bay Area city and county } \\
\text { building departments } \\
\text { have developed retrofit } \\
\text { standards. }\end{array}$ & $\begin{array}{l}\text { - Retrofit your home, if needed } \\
\text { (see pages } 24 \text { and } 25 \text { ). } \\
\text { - Secure the contents of your } \\
\text { home. }\end{array}$ \\
\hline Transport & $\begin{array}{l}\text { - As many as } 1,700 \text { road clo- } \\
\text { sures (12 times the number in } \\
\text { the Loma Prieta quake) will } \\
\text { snarl commutes. } \\
\text { - Only parts of the Bay Area } \\
\text { Rapid Transit System (BART) } \\
\text { will remain in operation. }\end{array}$ & $\begin{array}{l}\text { BART, Caltrans, and local } \\
\text { public works depart- } \\
\text { ments are retrofitting the } \\
\text { Bay Area's transportation } \\
\text { infrastructure. }\end{array}$ & $\begin{array}{l}\text { - Make a family plan for what } \\
\text { to do if you are separated } \\
\text { in a disaster (see pages } 22 \\
\text { and 23). } \\
\text { - Have earthquake disaster kits } \\
\text { at home, at work, AND in } \\
\text { your car (see page } 23 \text { ). }\end{array}$ \\
\hline
\end{tabular}




\section{Your Life Could Change Unexpectedly in the Next Quake. Consider...}

\section{Where will your family be?}

- Your children may be at school, day care, or other activities.

- Family members may be at work or commuting.

- Pets may run away or be injured.

After the 2001 magnitude 6.8 Nisqually earthquake, this

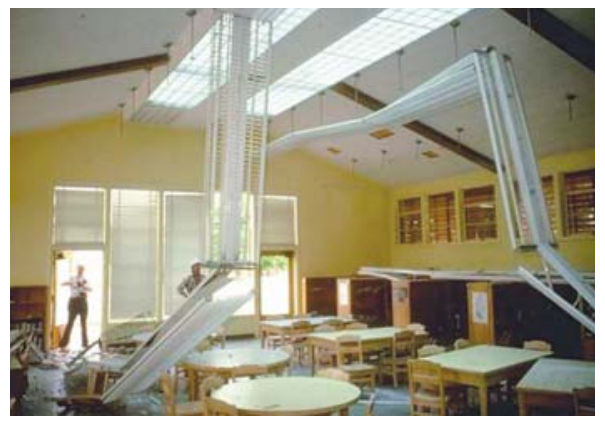

school in the Puget Sound area of Washington was closed for repair (Earthquake Engineering Research Institute photo).

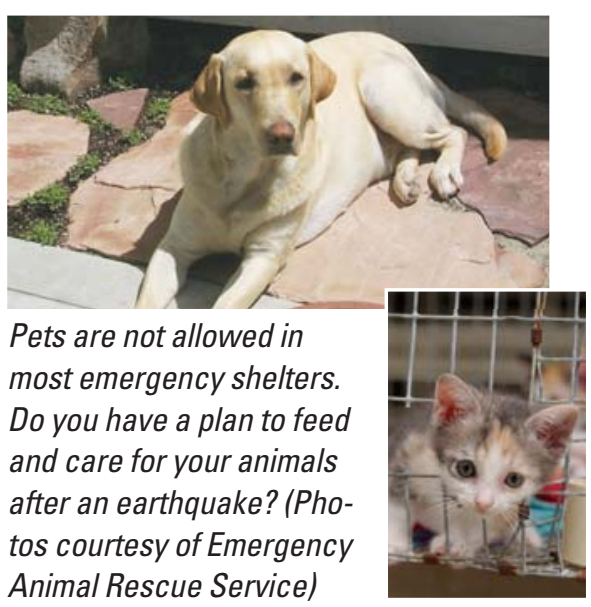

\section{Will you have medical services?}

- The 911 emergency system will likely be overloaded.

- Hospitals and other medical facilities may be damaged.

- Emergency rooms and trauma centers may be overwhelmed.

- Assisted living, critical care, and other health services such as dialysis may not be operational.

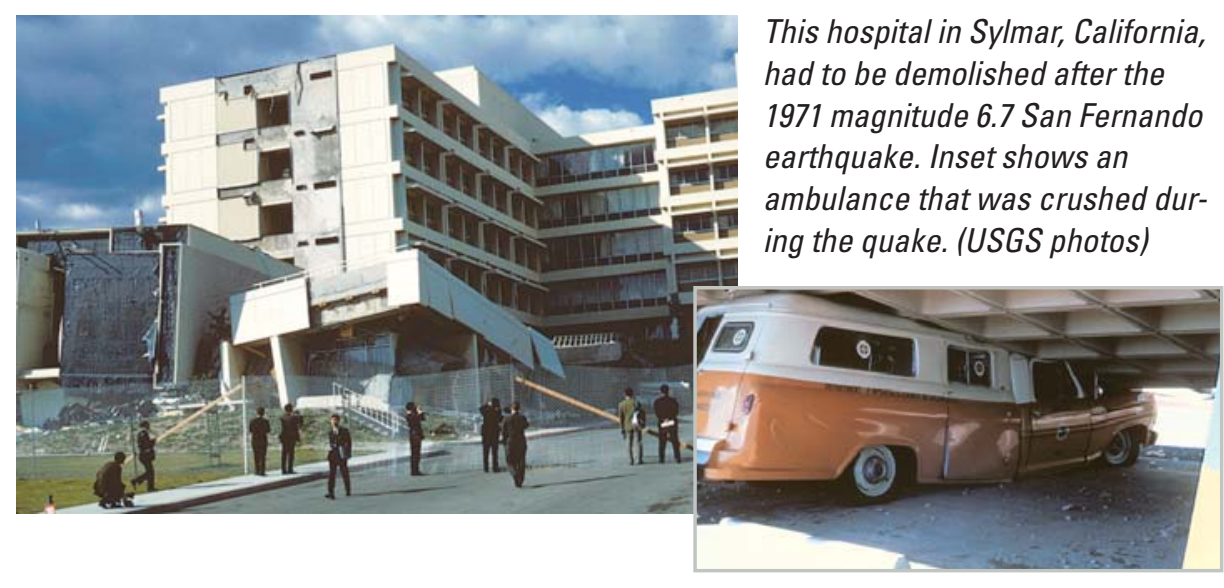

\section{Will you be able to get home?}

- Road damage and closures may restrict your ability to travel by car.

- Public transportation, including buses, Bay Area Rapid Transit (BART), ferries, and airports may experience closures or interruptions in service.

- Commute times may be dramatically increased.

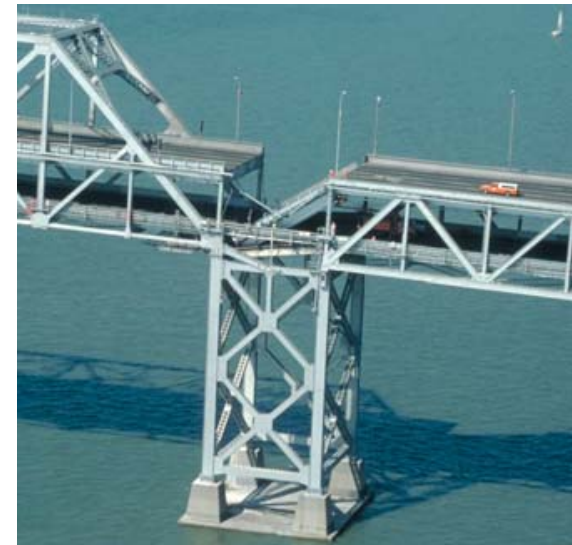

The 1989 magnitude 6.9 Loma Prieta earthquake caused this section of the San Francisco-Oakland Bay Bridge to collapse (USGS photo). 


\section{Will you be able to stay in your home?}

- Your home may be damaged and unsafe to live in.

- Your personal property may be damaged

This porch on a woodor destroyed.

- Construction materials and labor for repairs will be in limited supply and costs will increase.

- Rebuilding scams may be common.

- Availability of rental housing may be limited due to damage and high demand. frame house failed during the 1989 magnitude 6.9 Loma Prieta earthquake. The "red tag" indicates that this home is unsafe and must not be entered or occupied. (USGS photo)

\section{Can you live without the services you rely on?}

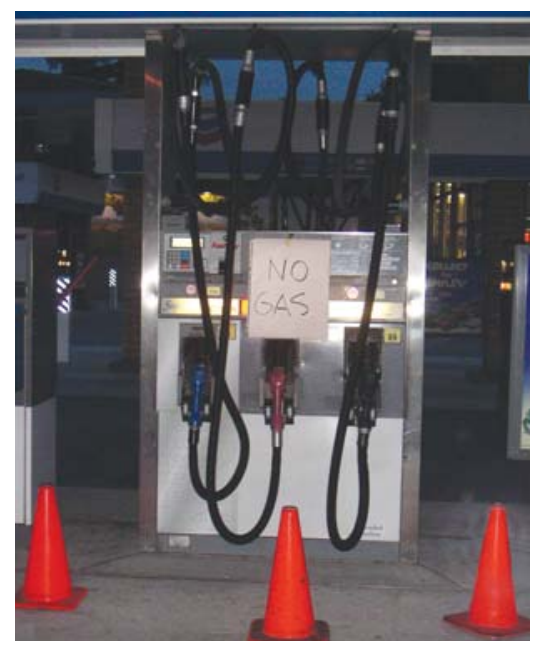

Where will you get your water, food, medicines, and gasoline after an earthquake? (USGS photo)
- Water may be in short supply.

- Natural gas and electric power may be out for days or weeks.

- Garbage and sewage services may be interrupted.

- Telephone, Internet, cell phone, and wireless communications may be overloaded or unavailable.

- Mail service may be disrupted or delayed.

- Gasoline may be in short supply, and rationing may be necessary.

- Bank operations may be disrupted, limiting access to cash, ATMs, or online banking.

- Grocery, drug, and other retail stores may be closed or unable to restock shelves.

\section{How will your job be affected?}

- Businesses may sustain damage and disruption-many small businesses require a long time to reopen or do not survive disasters.

- Your income may be affected-payroll checks or direct deposits may be delayed.

- Your workplace may become a temporary shelter for you or others.

- Supplies and deliveries will be interrupted.

This business in Santa Cruz, California, was nearly destroyed in the 1989 magnitude 6.9 Loma Prieta earthquake (USGS photo).

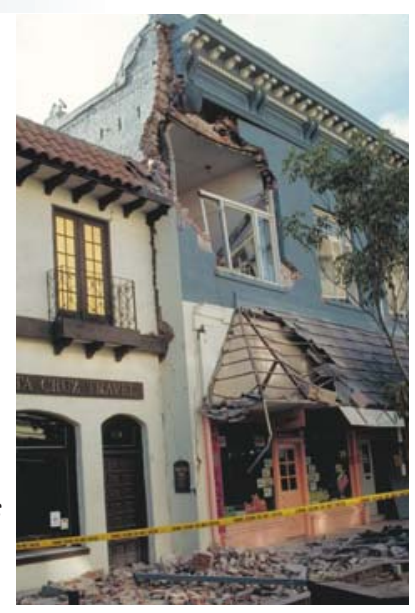

\section{How Will the American Red Cross Help?}

After an earthquake, the American Red Cross will help in the following ways:

- Opening and operating emergency shelters.

- Providing food at shelters and feeding locations and through mobile distribution.

- Obtaining and delivering other needed items such as water, baby supplies, and blankets.

- Assisting with the immediate mental-health needs of those affected.

- Providing for basic health needs at shelters and other locations.

- Helping with initial recovery through casework and referrals to other agencies and partners.

- Providing blood and blood products.

For more information go to: http://www.redcross.org/services/disaster/

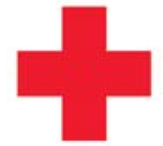

American Red Cross 


\section{Your Financial Situation Could Be Affected by a Quake...}

\begin{abstract}
A
id may not be immediately available following a major disaster. Without proper planning, the financial impact of an earthquake on you and your family could be devastating. Although many things are out of your control after a quake, your ability to recover financially depends on a number of factors that you can control. Prepare and follow a financial disaster recovery plan and you will be more likely to recover successfully. Consider the following:
\end{abstract}

\author{
This store was \\ temporarily closed \\ following the 2001 \\ magnitude 6.8 \\ Nisqually, Wash- \\ ington, earthquake \\ (photo courtesy \\ of The Olympian, \\ Olympia, Wash.).
}

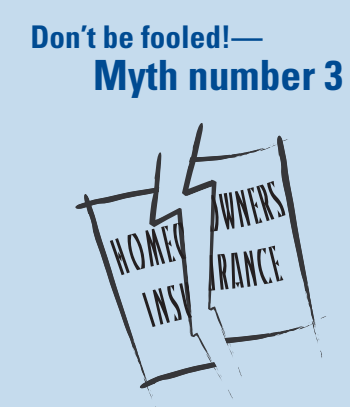

"HOMEOWNER'S INSURANCE WILL COVER ANY DAMAGE TO MY HOME OR BELONGINGS CAUSED BY AN EARTHQUAKE."

Most residential property insurance policies do not cover damage resulting from earthquakes. A separate earthquake insurance policy is one way to protect your home and the investments you have made in personal belongings. Investigate your options carefully to ensure that your assets are sufficiently protected (see http://www.EarthquakeAuthority.com/).

\section{Will you have money, food, and medicine?}

- Bank operations may be disrupted, limiting access to cash, ATMs, or online banking.

- Food, drug, and other retail stores where you shop may be closed or unable to restock shelves.

\section{Will you be able to recover financially?}

- You are still responsible for your existing debts, such as mortgage, lease, car, and credit-card payments.

- You may not have access to important financial records.

- Your assets are at risk without sufficient earthquake insurance.

- If you have earthquake insurance and experience loss, begin working with your insurer to file a claim as quickly as possible.

\section{Will your insurance cover your losses?}

- Homeowner's and renter's insurance policies do not cover losses related to earthquakes.

- A separate earthquake insurance policy is one way to help protect your home, in addition to seismic retrofitting.

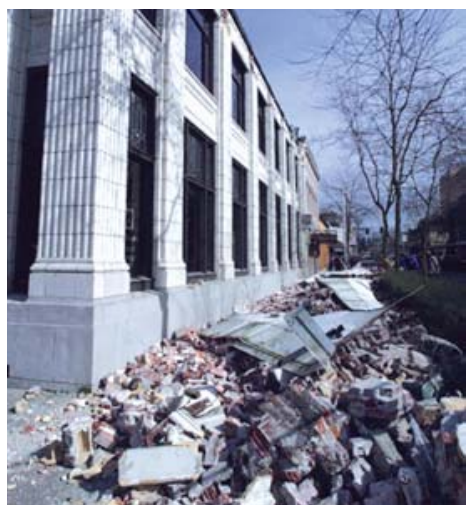

This bank was damaged in the 2001 magnitude 6.8 Nisqually, Washington, earthquake, requiring customers to seek services elsewhere (photo courtesy of The Olympian, Olympia, Wash.).

- Earthquake insurance also helps with additional living expenses in the days and weeks after earthquakes.

- A staggering $86 \%$ of California homeowners do not yet have earthquake insurance. 


\section{Does your small business have a recovery plan?}

- A business disaster recovery plan will make your business better able to survive in a post-disaster environment.

- Although physical assets can be replaced, emotional and social changes that affect businesses and their customers may remain long after a disaster.

- Businesses may not return to their previous revenue levels after a disaster; however, some businesses such as construction are likely to be in great demand following an earthquake.

\section{What will the Government do for you?}

- Federal disaster relief programs are designed to help you get partly back on your feet but not to replace everything you lose.

- The Department of Homeland Security's Federal Emergency Management Agency (FEMA) is tasked with responding to, planning for, and mitigating disasters.

- After the President signs a major disaster declaration, FEMA cooperates with other agencies, such as the Small Business Administration (SBA), in providing disaster relief.

- The primary form of disaster relief is low-interest loans to eligible individuals, homeowners, and businesses made available through the SBA to repair or replace damaged property and personal belongings not covered by insurance.

- The maximum SBA personal-property loan is $\$ 40,000$, and the maximum SBA real-property loan for primary home repair is $\$ 200,000$.

- FEMA disaster grants for emergency home repairs and temporary rental assistance are only available to individuals and households who do not qualify for loans.

- The average FEMA grant is less than $\$ 15,000$ (the maximum is $\$ 26,200$ ) — not enough to rebuild a home in the Bay Area!

- The Farm Service Agency (FSA) offers loans to assist agricultural businesses.

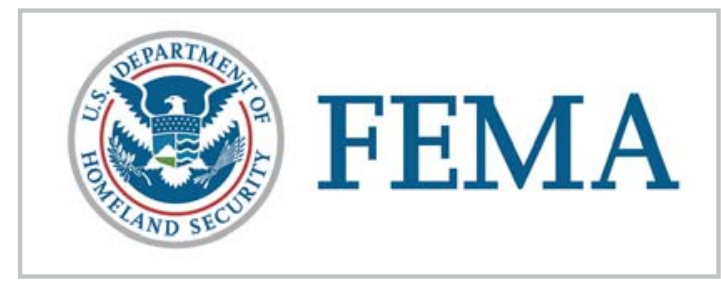

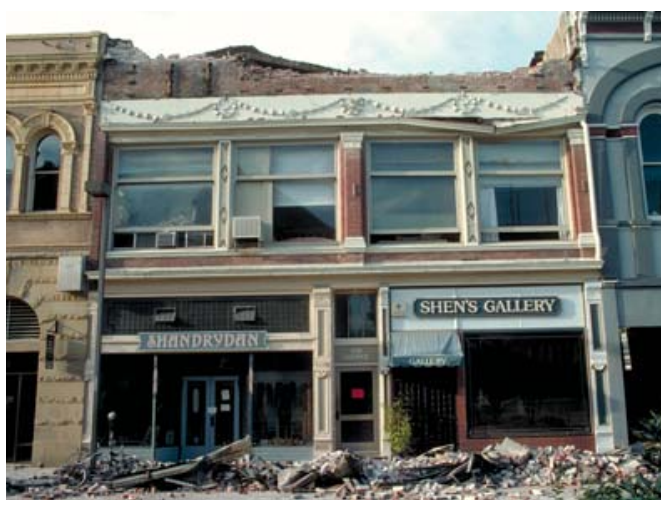

These small businesses in Santa Cruz, California, were heavily damaged in the 1989 magnitude 6.9 Loma Prieta earthquake, but both eventually reopened (USGS photo).

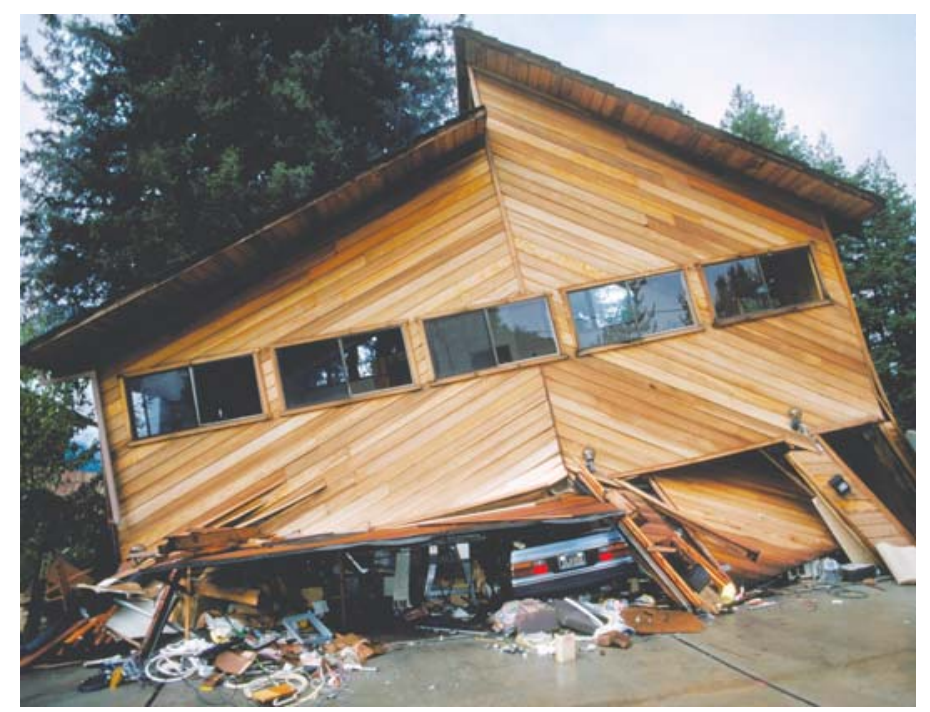

This home in the Santa Cruz Mountains, California, collapsed in the 1989 magnitude 6.9 Loma Prieta earthquake (USGS photo).

Useful Web sites

Financial preparation information:

http://www.redcross.org/services/disaster/ 0,1082,0_605_00.html

http://quake.abag.ca.gov/business/

Operation Hope Emergency Financial First Aid Kit (EFFAK): http://www.operationhope.org/

(Note: Both English and Spanish versions of the EFFAK are available at this site.)

\section{Disaster aid information:}

http://www.fema.gov/about/process/ 


\section{The Seven Steps to Earthquake Safety...}

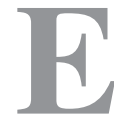
arthquakes in the Bay Area are inevitable, but damage from them is not! Steps you can take before, during, and after earthquakes will help make you and your family safer and reduce your injuries, damage, and losses:

- First and foremost, plan for the personal safety of you and your loved ones.

- Look into the safety of your home, workplace, and child's school-don't be afraid to ask your landlord, boss, or school's principal if they are aware of the hazards and have taken measures to make these places safer and more earthquake resistant.

- Find out if your home, workplace, and child's school could be subjected to seismic hazards, such as landsliding or liquefaction, in addition to strong shaking.

- Don't forget to think about likely economic impacts to you and your family from a major quake (see pages 16, 17, and 29).

The seven steps described in this section will help you to be safer in earthquakes. They are arranged as measures you should take before, during, and after quakes. In addition to following the steps at home, they should also be followed at schools and workplaces. If everyone makes an effort to follow these steps, billions of dollars could be saved, injuries avoided, and many deaths averted in the next big earthquake!

\section{You've learned your earthquake hazards, now follow these seven steps. . .}

\section{BEFORE A OUAKE:}

STEP 1. Identify potential hazards in your home and begin to fix them (page 20).

STEP 2. Create a disaster-preparedness plan (page 22).

STEP 3. Prepare disaster kits (page 23).

STEP 4. Identify your building's potential weaknesses and begin to fix them (page 24).

DURING A QUAKE:

STEP 5. Protect yourself during earthquake shaking—DROP, COVER, AND HOLD ON (page 26).

\section{AFTER A QUAKE:}

STEP 6. After the quake, check for injuries and damage (page 27).

STEP 7. When safe, continue to follow your disaster-preparedness plan (page 28). 


\section{Follow the Seven Steps to Earthquake Safety}

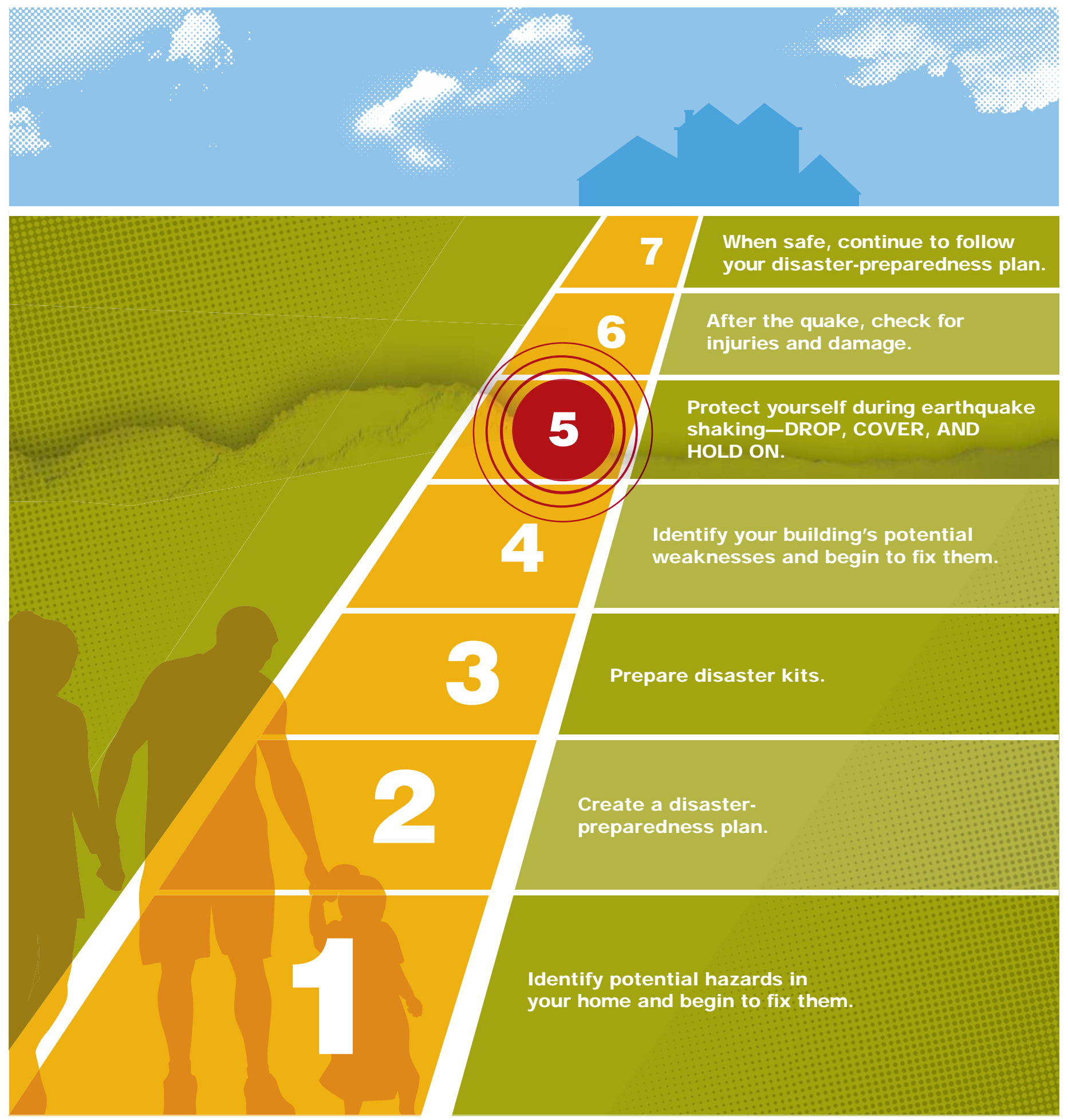




\section{STEP 1-Identify Potential Hazards in Your Home and Begin to Fix Them}

T 'he first step to earthquake safety is to look around your home and identify all unsecured objects that might fall during shaking.

START NOW by moving heavy furniture, such as bookcases, away from beds, couches, and other places where people sit or sleep! Also make sure that exit paths are clear of clutter.

Simple and inexpensive things that you can do now will help reduce injuries and protect belongings in a quake. Most hardware and home-improvement stores carry earthquake-safety straps, fasteners, and adhesives that you can easily use to secure your belongings.

The following tips describe simple solutions to situations in your home that could be dangerous during earthquake shaking. If these have not yet been done in your home, take action now:

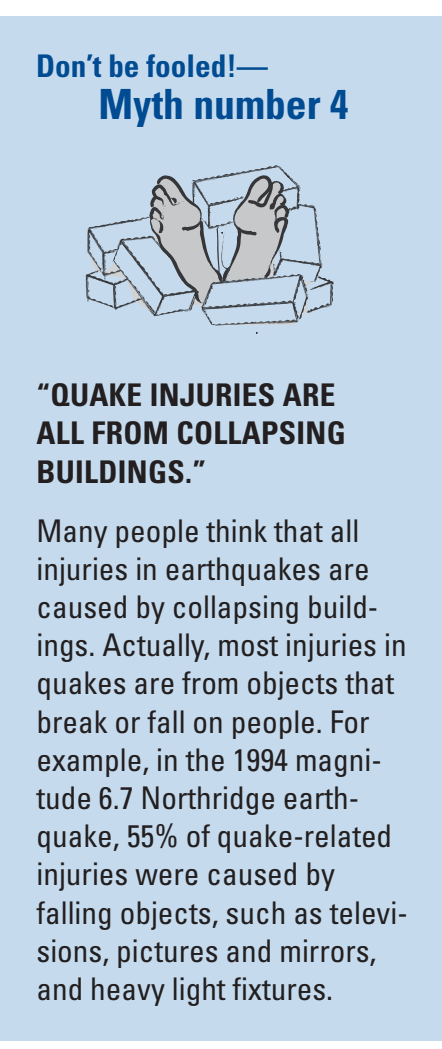

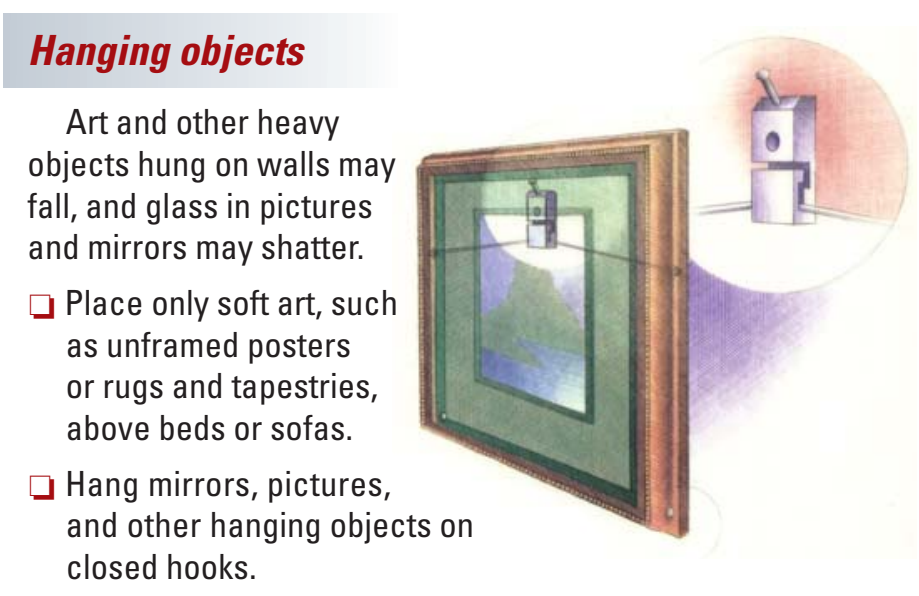

\section{Objects on open shelves and tabletops}

Collectibles and other loose objects can become dangerous projectiles.

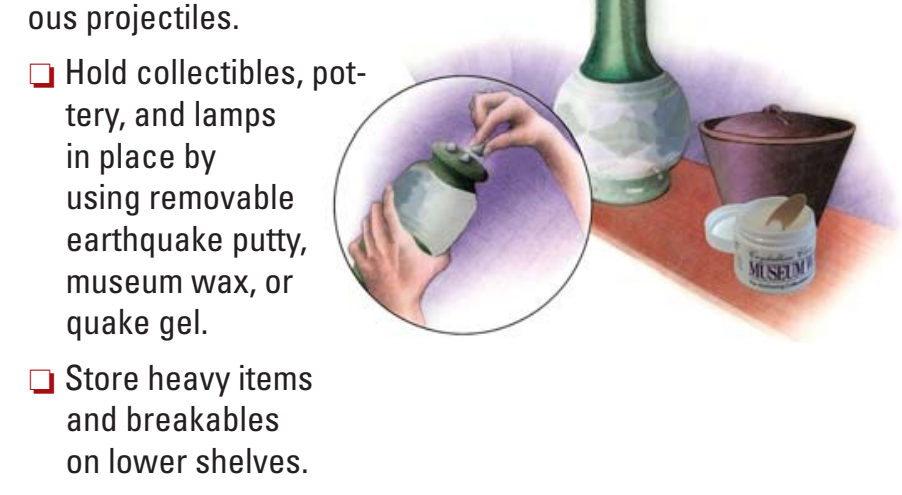

\section{Furniture}

Tall, top-heavy furniture, such as bookcases and entertainment centers, may fall and injure you.

$\square$ Secure both top corners of tall furniture into a wall stud, not just to the drywall.

$\square$ Flexible-mount fasteners, such as nylon straps, allow furniture independent movement from the wall, reducing strain on studs.

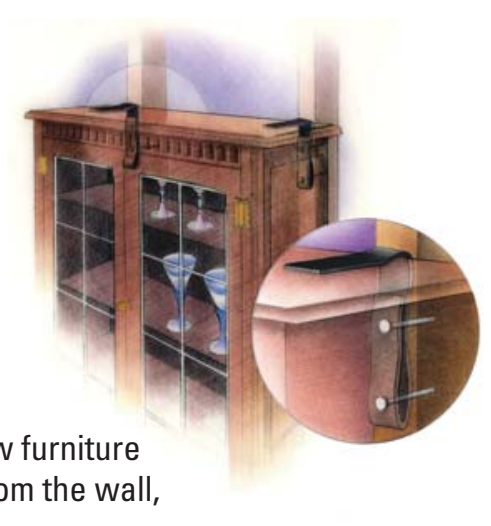




\section{Check the boxes!}

\section{Water and gas pipes}

Water or gas pipes anywhere in your home can break. Water leaks can cause extensive damage, and gas leaks are a major fire hazard.

$\square$ Have a plumber evaluate, replace, and properly secure rusted or worn water and gas pipes.

$\square$ If not already done, have a plumber replace rigid gas connections to water heaters, stoves, dryers, and other gas appliances with flexible (corrugated) stainless-steel gas connectors (see below).

$\square$ Excess-flow gas-shutoff valves for individual appliances, which stop gas flow in case of a catastrophic leak, are also now available for use with flexible connectors.

\section{Water heaters}

Unsecured water heaters may fall over, rupturing rigid water and gas connections.

$\square$ Water heaters are required to be anchored to wall studs or masonry with metal straps and lag screws. Kits are available at hardware stores and home centers.

$\square$ If not already done, have a plumber install flexible (corrugated) copper water connectors.

\section{Flexible} gas connector
Flexible water connectors

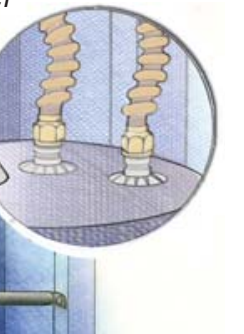

\section{In the kitchen}

Glassware and china may crash to the floor if cabinet doors are unsecured. Gas appliances can shift, rupturing their gas connections.

$\square$ Secure all cabinets doors, especially those overhead, to help prevent contents from falling out during quakes. Use latches designed for child proofing or earthquake or boat safety.

$\square$ Secure refrigerators and other major appliances to walls using earthquake appliance straps.

\section{In the garage or utility room}

Items stored in garages and utility rooms can fall, causing injuries, damage, and hazardous spills or leaks.

$\square$ Move flammable or hazardous materials to low areas that are secure.

$\square$ Ensure that items stored above or beside vehicles cannot fall, damaging or blocking them.

\section{Home electronics}

Large electronic devices may fall, causing injuries and damage. They are also costly to replace.

$\square$ Secure TVs, stereos, computers, and microwave ovens with flexible nylon straps and buckles for easy removal and relocation.

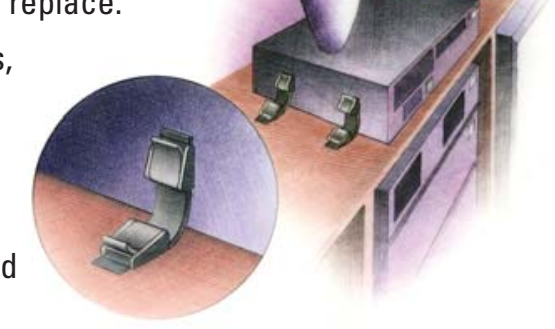

Move on to STEP 2. 


\section{STEP 2 - Create a Disaster-Preparedness Plan}

W ill everyone in your household know how to react during and after strong earthquake shaking? To be ready for the quakes that are certain to happen in the Bay Area, it is important that your family have a disaster-preparedness plan. Hold occasional earthquake "drills" to practice your plan. Share your disaster plan with your neighbors and discuss key points with babysitters, house sitters, and house guests. Your plan should include most of the following:

\section{Plan NOW to be safe during an earthquake:}

In a strong earthquake, individual survival skills will be crucial.

$\square$ Practice "drop, cover, and hold on." (See STEP 5, page 26)

$\square$ Identify safe spots in every room, such as under sturdy desks and tables.

$\square$ Learn how to protect yourself no matter where you are when an earthquake strikes. (See STEP 5, page 26)

\section{Plan NOW to respond after an earthquake:}

Doing the following will enable you to help your family and others after a strong quake.

$\square$ Keep shoes and a working flashlight next to each bed.

$\square$ Teach everyone in your household to use emergency whistles and (or) to knock 3 times repeatedly if trapped. Rescuers searching collapsed buildings will be listening for sounds.

$\square$ Identify the needs of household members and neighbors with special requirements or situations, such as use of a wheelchair, walking aids, special diets, or medication.

$\square$ Take a Red Cross first aid and CPR (cardiopulmonary resuscitation) training course. Learn who in your neighborhood is trained in first aid and CPR.

$\square$ Know the locations of utility shutoffs and keep needed tools nearby. Know how to turn off the gas, water, and electricity to your home. Only turn off the gas if you smell or hear leaking gas. (See STEP 6, page 27)

$\square$ Get training from your local fire department in how to properly use a fire extinguisher.

$\square$ Install smoke alarms and test them monthly. Change the battery once a year, or sooner if the alarm emits a "chirping" sound (low-battery signal).

$\square$ Check with your fire department to see if there is a Community Emergency Response Team (CERT) in your area. If not, ask how to start one.

\section{Plan NOW to communicate and recover after an earthquake:}

Don't wait until the next earthquake to do the following.

$\square$ Locate a safe place outside of your home for your family to meet after the shaking stops.

$\square$ Establish an out-of-area contact person who can be called by everyone in the household to relay information.

$\square$ Provide all family members with a list of important contact phone numbers.

$\square$ Determine where you might live if your home cannot be occupied after an earthquake or other disaster (ask friends or relatives).

$\square$ Learn about the earthquake plan developed by your children's school or day care, and keep your children's school emergency release cards current.

$\square$ Keep copies of insurance policies, financial records, and other essential documents in a secure location, such as with your household disaster kit. Include a household inventory (a list and photos or video of your belongings).

Move on to STEP 3.

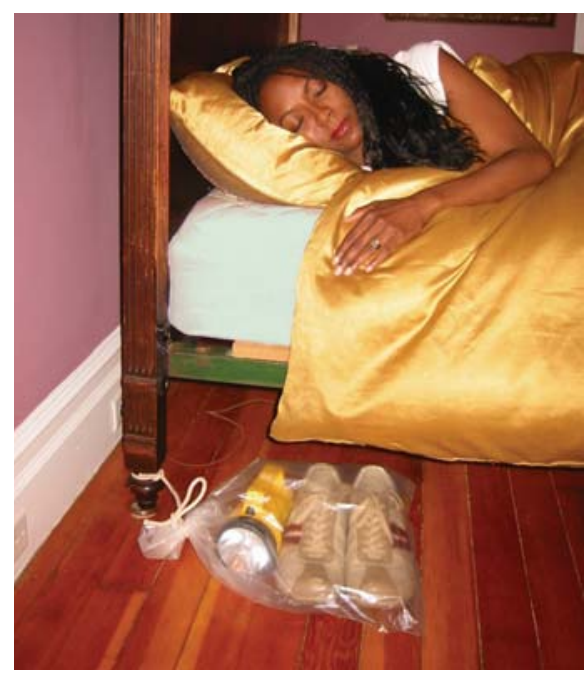

Your family may be sleeping when the next strong quake hits the Bay Area. After the shaking stops, the lights may be out and broken glass and other dangerous debris may litter the floor, making it unsafe to walk barefoot. Keep a flashlight and a pair of sturdy shoes secured to or within reach of everyone's bed. A good way to do this is to use a drawstring bag tied to a bedpost at the head of the bed for each occupant. 


\section{STEP 3-Prepare Disaster Kits}

\section{Personal Disaster Kits}

Everyone in your family should have their own personal disaster kits. These kits are collections of supplies they may need when a quake strikes, no matter where they are in the Bay Area.

Personalize these kits and keep them where they can easily be reached - at home, in the car, at work or school. A backpack or other small bag is best for these kits so that they can be easily carried in an evacuation. Include the following items:

Medications, a list of prescriptions, copies of medical insurance cards, doctors' names and contact information.

$\square$ Medical consent forms for dependents.

$\square$ First aid kit and handbook.

- Spare eyeglasses, personal hygiene supplies, and sturdy shoes

$\square$ Bottled water.

$\square$ Whistle (to alert rescuers to your location).

$\square$ Emergency cash.

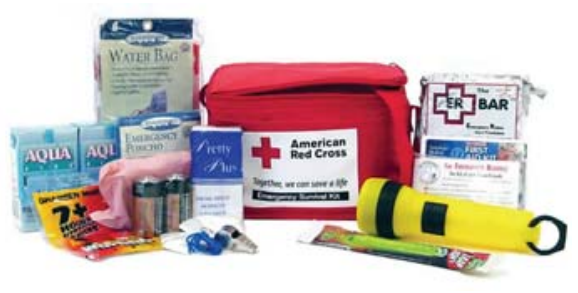

$\square$ Personal identification

$\checkmark$ List of emergency contact phone numbers.

$\checkmark$ Snack foods high in calories.

$\square$ Emergency lighting — light sticks and (or) a working flashlight with extra batteries and light bulbs (hand-powered flashlights are also available).

$\square$ Comfort items, such as games, crayons, writing materials, and teddy bears.

\section{Household Disaster Kit}

Electrical, water, transportation, and other vital systems can be disrupted for several days after a large earthquake. Emergency response agencies and hospitals will likely be overwhelmed and unable to provide you with immediate assistance.

To help your family cope after a strong earthquake, store a household disaster kit in an easily accessible location, preferably outdoors (not in your garage). This kit, which complements your personal disaster kits, should be in a large watertight container that can be easily moved and should hold at least a 3- to 5-day supply of the following items:

$\square$ Drinking water (minimum one gallon per person per day).

- First aid supplies, medications, and essential hygiene items, such as soap, toothpaste, and toilet paper.

$\square$ Emergency lighting — light sticks and (or) a working flashlight with extra batteries and light bulbs (hand-powered flashlights are also available).

$\square$ A hand-cranked or battery-operated radio (and spare batteries).

$\square$ Canned and packaged foods and cooking utensils, including a manual can opener.

- Items to protect you from the elements, such as warm clothing, sturdy shoes, extra socks, blankets, and perhaps even a tent.

- Heavy-duty plastic bags for waste and to serve other uses, such as tarps and rain ponchos.

$\square$ Work gloves and protective goggles.

$\checkmark$ Pet food and pet restraints.

$\square$ Copies of vital documents, such as insurance policies and personal identification.

\section{A Special Note About Children}

Before the next earthquake, spend time with your kids to discuss what might occur. Involve them in developing your disaster plan, preparing disaster supplies kits (ask them what game or toy they want to include), and practicing "drop, cover, and hold on."

In the days after a quake, kids need extra contact and support. They may be frightened and under great stress, and aftershocks won't let them forget the experience. Parents may have to leave children with others in order to deal with the emergency, and this can be scary. Whenever possible,

finclude your children in the earthquake recovery process.

Resources for kids to learn about disaster preparedness: http://www.abag.ca.gov/bayarea/eqmaps/kids.html www.fema.gov/kids/ http://earthquake.usgs.gov/4kids/
NOTE: Replace perishable items like water, food, medications, and batteries on a yearly basis.

\section{Move on to STEP 4}

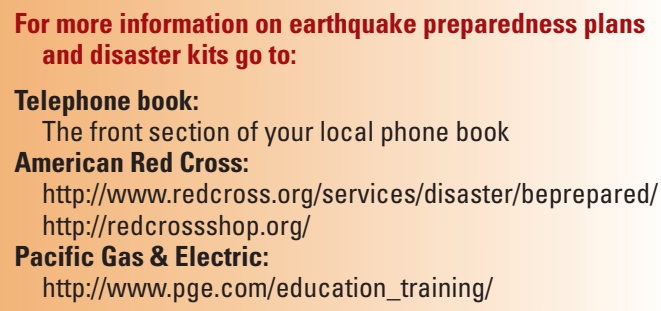

For more information on earthquake preparedness plans and disaster kits go to:

Telephone book:

The front section of your local phone book

American Red Cross:

http://www.redcross.org/services/disaster/beprepared/ http://redcrossshop.org/

Pacific Gas \& Electric:

http://www.pge.com/education_training/ 


\section{STEP 4-Identify Your Building's Potential Weaknesses and Begin to Fix Them}

s your house, condo, or apartment strong enough to withstand an earthquake?

\section{If you live in a single-family home or duplex...}

You can use the quiz at right to see if your home is likely to be so badly damaged in a future quake that people might be injured or that it would be unsafe to occupy.

If your home scores 13 or more points on the quiz, you probably should have a structural engineer, architect, or contractor evaluate it unless it has been strengthened in the last few years. They will check to see if it is strong enough to keep you and your family reasonably safe in a quake. For example:

- Does your home have enough bolts connecting the "sill plate" to the foundation? (See below)

- Is there plywood on the inside surface of the crawl space extending from the sill plate to the base of the floor joist above to prevent the wall studs from collapsing?

- Are there metal brackets connecting the rim joists to the top plates?

- Is the ground floor a large open space lacking interior walls (weak or "soft" story)?

- Are there large openings in the walls of the lower story, such as a garage door, that should be better braced?

- Is your home a hillside house that was not adequately designed to withstand strong earthquake shaking?

Once you determine if your home needs retrofitting, identify problems, prioritize how and when to fix them, and get started!

The latest recommendations of structural engineers, contractors, and city building officials who are experts on retrofitting are available on the ABAG web site at http://quake. abag.ca.gov/fixit/.
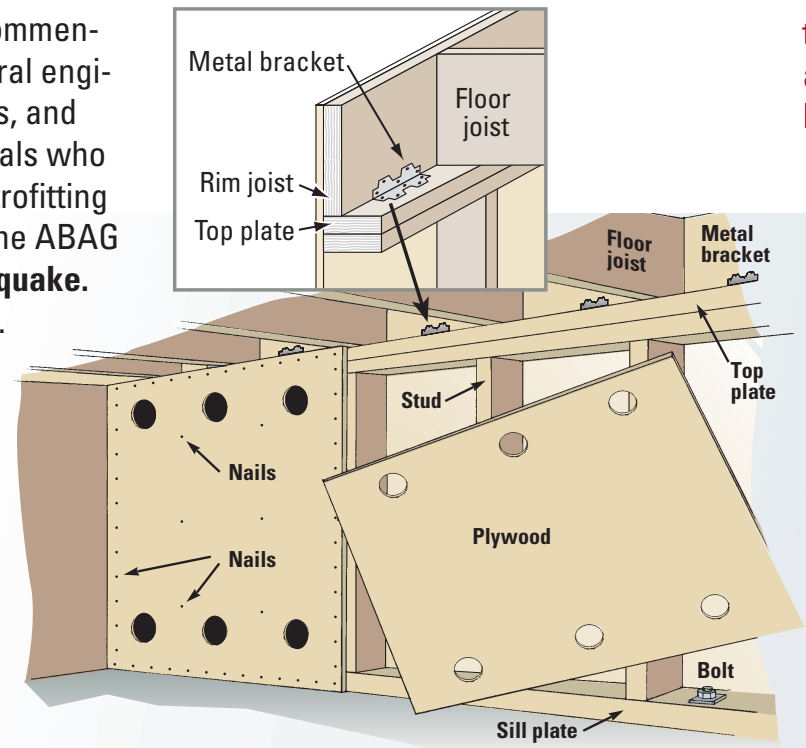

If you live in a single-family home or duplex, the strength of your home depends on when it was built, its style of construction, and its location.

1. When was your home built?

口 Before $1960=5$ points

口1961-1978 $=3$ points

$\square$ After $1978=1$ point

\section{How tall is your home?}

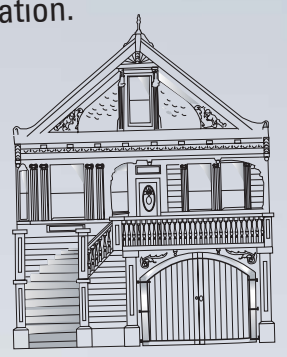

$\square 2$ or more stories with living area above a garage $=5$ points

$\square$ Split level, on a hillside or gentle slope $=6$ points

$\square$ story, 3 or more steps up to the front door $=4$ points

$\square 1$ story, less than 3 steps up to the front door $=1$ point

\section{How hard is the ground likely to shake under your}

home?

$\square$ Portions of the Bay Area shown as yellow or green in color on the shaking hazard map (page 8 ) $=5$ points

$\square$ Elsewhere in the Bay Area $=7$ points

\section{TOTAL POINTS =}

If your home scores 13 or more points on the quiz, you probably should have an engineer, architect, or contractor evaluate it unless it has been strengthened in the past few years.

\section{Strengthening your crawl space}

The number of foundation bolts, linear feet of plywood, and floor-to-wall connections (brackets) that are required to seismically retrofit your home varies depending on its size and weight. Remember, earthquakes will find the weak spots in your house. So, if you add bolts but not plywood, you will still have a problem when the ground shakes! 


\section{Follow the Seven Steps to Earthquake Safety}

If you live in a condominium or apartment...

Many condominiums and apartments have parking on the ground floor. These weak or "soft" first stories may lean or collapse in an earthquake.

Some multi-story buildings in the Bay Area can have problems because they were constructed before 1972 of concrete or brick that is inadequately reinforced. Many cities have requirements that these buildings be seismically retrofitted. You are less likely to be killed in a retrofitted building, but you may not be able to reoccupy it after a quake.

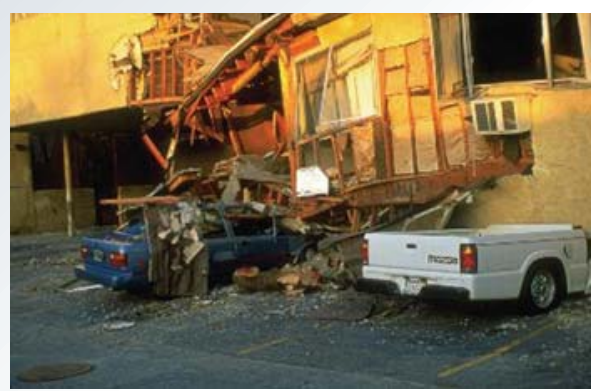

The "soft" first story of this apartment building collapsed in the 1994 magnitude 6.7 Northridge earthquake, crushing cars below and severely damaging the floors above (FEMA photo).

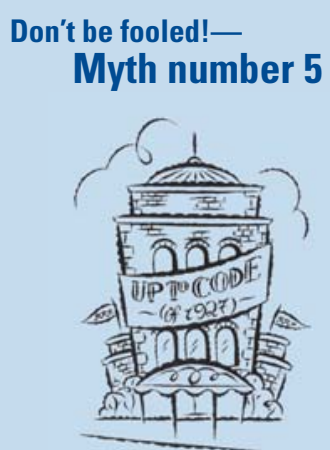

\section{"WE HAVE GOOD BUILDING CODES, SO WE MUST HAVE SAFE BUILDINGS."}

The best building code in the world does nothing for buildings built before the code was enacted. Although building codes used in California have some of the strictest seismic provisions in the world, many older buildings have not been "retrofitted" to meet updated codes. Retrofitting - fixing problems in older buildings-is the responsibility of a building's owner.
Go to http://quake.abag.ca.gov/fixit/ to take a quiz to see if your apartment building or condominium may need retrofitting. This Web site also has links to information that can help your landlord find appropriate ways to improve the strength of your building.

\section{If you live in a mobile home...}

Look under your home. If you only see a metal or wood "skirt" on the outside with concrete blocks or steel tripods or jacks supporting your home, you need to have an "engineered tie-down system" or an "earthquake-resistant bracing system" (ERBS) installed.

An ERBS should have a label on the bracing that says, "Complies with the California Administrative Code, Title 25, Chapter 2, Article 7.5."

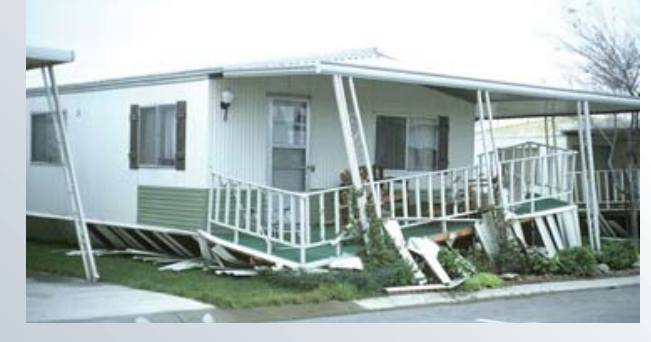

Mobile home damage in the 1980 magnitude 5.8 Livermore earthquake (photo courtesy NISEE).

\section{Brick chimneys can collapse if shaken...}

Stay away from chimneys and fireplaces during shaking! Collapsing chimneys cause many injuries in earthquakes60,000 chimneys fell in the 1994 magnitude 6.7 Northridge earthquake.

You can reduce the chance of bricks falling through a sheetrock ceiling in a quake by putting sheets of plywood above ceiling framing. However, "retrofitting" masonry chimneys with bracing or strapping is not an effective safety measure, because they may still fall as a unit when exposed to strong shaking.

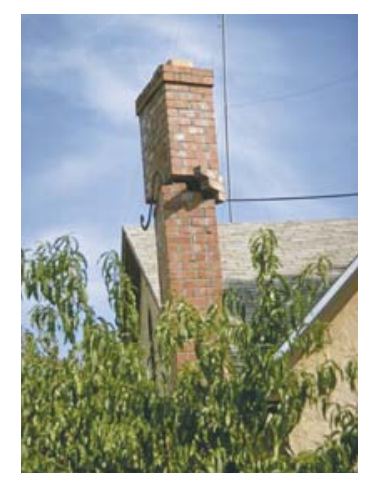

This chimney broke and nearly fell in the 1969 magnitude 5.6 Santa Rosa earthquake (photo courtesy NISEE). 


\section{STEP 5-Protect Yourself During Earthquake Shaking}

T

he previous pages have

concentrated on getting you

ready for future earthquakes in the Bay Area, but what should you do when the shaking starts?

\section{If you are indoors...}

- "DROP, COVER, AND HOLD ON." If you are not near a desk or table, drop to the floor against an interior wall and protect your head and neck with your arms.

- Avoid exterior walls, windows, hanging objects, mirrors, tall furniture, large appliances, and cabinets filled with heavy objects.

- Do not go outside until well after the shaking stops!

In bed

Hold on and stay there, protecting your head with a pillow. You are less likely to be injured staying where you are. Broken glass on the floor can cause injuries; be sure to put shoes on before stepping on the floor (see STEP 2, page 22)!

\section{In a high rise building}

DROP, COVER, AND HOLD ON. Avoid windows and other hazards. Do not use elevators. Do not be surprised if sprinkler systems or fire alarms activate.

\section{At work}

DROP, COVER, AND HOLD ON. Know your workplace's earthquake safety plan and put it into action. When safe, move to a specified meeting location.

\section{In a public building or theater}

\section{DROP, COVER, AND HOLD ON if pos-} sible. If in a theater seat, duck down and protect your head and neck with your arms. Don't try to leave until the shaking is over. Then walk out slowly, watching for fallen debris or anything that could fall on you in aftershocks.

\section{If you are outdoors...}

Move to a clear area if you can safely do so; avoid buildings, powerlines, trees,

\section{"DROP, COVER, AND HOLD ON"}

If you are indoors, when you feel strong earthquake shaking, drop to the floor, take cover under a sturdy desk or table, and hold on to it firmly until the shaking stops.

and other hazards. Always assume fallen powerlines are live!

\section{Near tall buildings}

Windows, facades, and architectural details are often the first parts of a building to collapse. Get away from this danger zone when shaking starts. Take refuge in a safe building or an open space.

\section{Driving}

When able, safely pull over to the side of the road, stop, and set the parking brake. Avoid overpasses, bridges, powerlines, signs, trees, and other things that might collapse or fall on the vehicle. Stay inside the vehicle until the shaking is over. If a powerline falls on the vehicle, stay inside until a trained person removes the hazard.

\section{In a stadium}

Stay at your seat and protect your head and neck with your arms. Don't try to leave until the shaking is over. Then exit slowly, avoiding debris and watching for anything that could fall in aftershocks.

\section{Near the shore}

Tsunamis from local earthquakes may flood low-lying coasts within minutes of the quake. Distant, large earthquakes can produce tsunamis that may arrive hours later at California's beaches. If you feel a strong quake, hear a tsunami warning, or notice the water suddenly withdrawing from the beach, evacuate immediately to higher ground. Tsunami waves may continue to arrive for hours, so do not return to the shore until an "all clear message" has been issued. For more tsunami survival tips go to http:// pubs.usgs.gov/circ/c1187/.

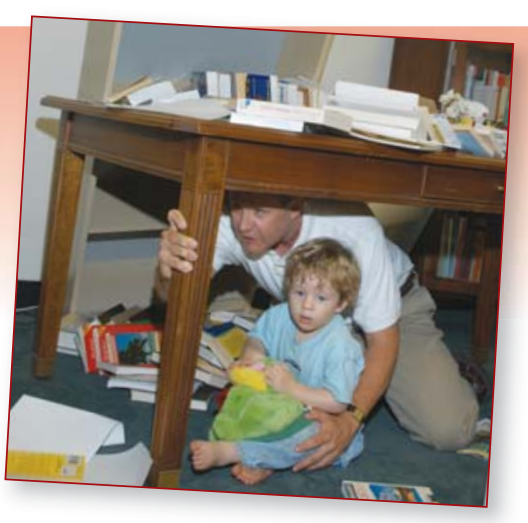

\section{Below a dam}

Dams can fail during a major earthquake. Catastrophic failure is unlikely, but if you are downstream from a dam, you should know flood-zone information and have prepared an evacuation plan. For more information go to the Association of Bay Area Governments Web site at http:// www.abag.ca.gov/bayarea/eqmaps/ eqfloods/floods.html.

Move on to STEP 6

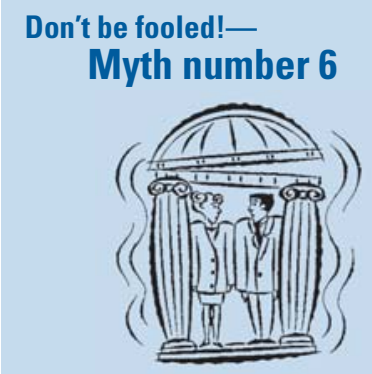

"HEAD FOR THE DOORWAY."

In the early days of California, many homes were made of adobe bricks with wooden doorframes. After a powerful earthquake, doorframes were sometimes the only parts of these houses still standing. From this came the myth that a doorway is the safest place to be during an earthquake. Today, few people in the Bay Area live in old, unreinforced adobe houses. In modern houses, doorways may be no stronger than any other part of the house and do little to protect you from falling debris. You are safer under a table, so "DROP, COVER, AND HOLD ON." 


\section{Follow the Seven Steps to Earthquake Safety}

\section{STEP 6 - After the Quake, Check for Injuries and Damage}

O

nce earthquake shaking has

stopped, follow your disaster preparedness plans (see Step

2, page 22). Most importantly:

\section{Check for injuries}

NOTE: The manual in your first aid kit and the front pages of your telephone book have instructions on first aid measures.

- Check yourself for serious injuries before helping others. Protect your mouth, nose, and eyes from dust.

- If a person is bleeding, put direct pressure on the wound. Use clean gauze or cloth, if available.

- If a person is not breathing, administer rescue breathing.

- If a person has no pulse, begin CPR (cardiopulmonary resuscitation).

- Do not move seriously injured persons, unless they are in immediate danger of further harm.

- Cover injured persons with blankets or additional clothing to keep them warm.

\section{Check for damage causing hazardous conditions}

- Fire-If possible, put out small fires in your home or neighborhood immediately. Call for help, but don't wait for the fire department.

- Gas leaks-Only turn off the gas if you suspect a leak because of broken pipes or detect the odor or sound of leaking natural gas. Use a manual gas shut off wrench to close your main gas valve by turning it counterclockwise. Don't turn gas back on by yourself-wait for the gas company! (Your telephone book has information on this topic.)
-Damaged electrical wiring — Shut off power at the main breaker switch if there is any damage to your home wiring. Leave the power off until the damage is repaired! (Your telephone book also has information on this topic.)

- Downed utility lines-If you see downed power lines, consider them energized and keep yourself and others well away from them. Never touch downed power lines or any objects in contact with them!

- Falling items-Beware of heavy items tumbling off shelves when you open closet and cupboard doors.

- Spills-Use extreme caution; when in doubt, leave your home! Spilled medicines, drugs, or other relatively non-toxic substance can be cleaned up. Potentially harmful materials, such as bleach, lye, garden chemicals, paint, and gasoline or other flammable liquids should be isolated or covered with an absorbent material, such as dirt or cat litter.

-Damaged masonry—Stay away from brick chimneys and walls. They may be weakened and could topple during aftershocks. Don't use a fireplace with a damaged chimney, as this could start a fire or trap toxic gases in your home!

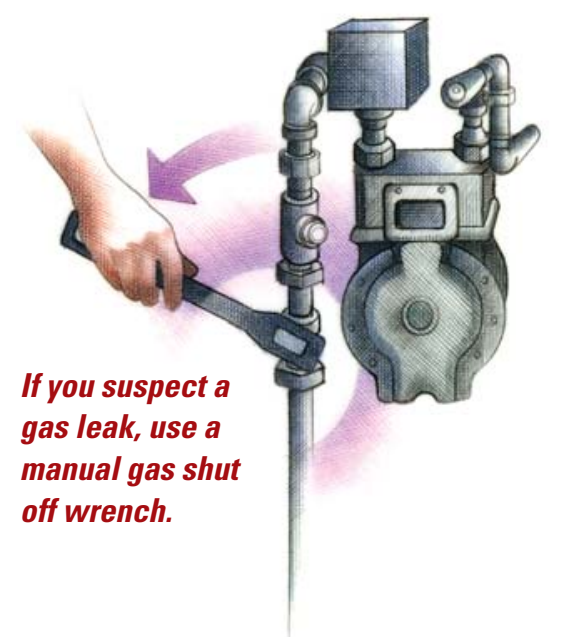

If your home is seriously damaged...

If your home is structurally unsafe or threatened by a fire or other secondary disaster, you need to evacuate. However, shelters may be overcrowded and initially lack basic services, so do not leave home just because utilities are out of service or your home and its contents have suffered moderate damage.

If you evacuate, tell a neighbor and your family point-of-contact where you are going. Take the following, if possible, when you evacuate:

\section{Bring to a shelter}

$\square$ Personal disaster supply kits (see STEP 3, page 23).

$\square$ Supply of water, food, and snacks.

$\square$ Blanket, pillow, and air mattress or sleeping pad.

$\square$ Change of clothing and a jacket.

$\square$ Towel and washcloth.

$\square$ Diapers, formula, food, and other supplies for infants.

$\square$ A few family pictures or other small comfort items, such as dolls or teddy bears for children.

$\square$ Personal identification and copies of household and health insurance information.

$\square$ Books and games (especially for children).

\section{However, do not bring}

- Pets (service animals for people with disabilities are allowed — bring food for them).

- Large quantities of unnecessary clothing or other personal items.

- Valuables that might be lost, stolen, or take up needed space.

\section{Move on to STEP 7.}

\author{
Related Web links: \\ American Red Cross \\ http://www.redcross.org/ \\ http://www.prepare.org/ \\ Association of Bay Area Governments \\ http://quake.abag.ca.gov/
}




\section{STEP 7-When Safe, Continue to Follow Your Disaster- Preparedness Plan}

\author{
nce you have met your and \\ your family's immediate \\ needs after the next strong Bay \\ Area earthquake, continue to fol- \\ low your disaster-preparedness \\ plan (see Step 2, page 22).
}

\section{The first days after the earthquake. . .}

In the days following a damaging quake, pay special attention to the following:

\section{Safety first}

- Do not reenter your home until you know it is safe.

- Be sure there are no gas leaks at your home before using open flames (lighters, matches, candles, or grills) or operating any electrical or mechanical device that could create a spark (light switches, generators, chain saws, or motor vehicles).

- Check for chemical spills, faulty electrical wiring, and broken water lines. Water in contact with faulty wiring is a shock hazard.

- Unplug broken or toppled light fixtures or appliances. These could start fires when electricity is restored.

- Never use the following indoors: camp stoves, kerosene or gas lanterns or heaters, gas or charcoal grills, or gas generators, as these can release deadly carbon monoxide gas or be a fire hazard in aftershocks.

\section{Be in communication}

- Turn on your portable or car radio and listen for information and safety advisories.

- Place all phones back on their cradles.

- Call your out-of-area contact, tell them your status, and then stay off the phoneemergency responders need the phone lines for life-saving communications.

- Check on your neighbors.

\section{Check your food and water supplies}

- If power is off, plan meals so as to use up refrigerated and frozen foods first. If you keep the door closed, food in your freezer may be good for a couple of days.

- If your water is off, you can drink from water heaters, melted ice cubes, or canned vegetables. Avoid drinking the water from swimming pools or hot tubs; use it to fight fires.

\section{The first weeks after the earthquake. . .}

This is a time of transition. Although aftershocks may continue, you will now work toward getting your life, your home and family, and your routines back in order. Emotional care and recovery are just as important as healing physical injuries and rebuilding a home. Make sure your home is safe to occupy and not in danger of collapse in aftershocks. If you were able to remain in your home or return to it after a few days, you will have a variety of tasks to accomplish while reestablishing routines:

\section{Tasks}

- If your gas was turned off, you will need to arrange for the gas company to turn it back on.

- If the electricity went off and then came back on, check your appliances or electronic equipment for damage.

- If water lines broke, look for water damage.

- Locate or replace critical documents that may have been misplaced, damaged, or destroyed.

- Contact your insurance agent or company right away to begin your claims process.

- Contact the Federal Emergency Management Agency (FEMA) to find out about financial assistance (see page 17).

- If you cannot live at your home, set up an alternative mailing address with the post office.

\section{If you cannot stay in your home...}

The American Red Cross (ARC) offers immediate emergency assistance with housing needs. ARC also supports shelter operations prior to a Presidential declaration of a Federal disaster.

Once a Presidential declaration has been issued, the Federal Emergency Management Agency (FEMA) may activate the "Assistance for Individuals and Households Program." This program includes:

- Home-repair cash grants; the maximum of Federal grant available is $\$ 26,200$.

- Housing Assistance in the form of reimbursement for short-term lodging expenses at a hotel or motel.

- Rental assistance for as long as 18 months in the form of cash payment for a temporary rental unit or a manufactured home.

- If no other housing is available, FEMA may provide mobile homes or other temporary housing.

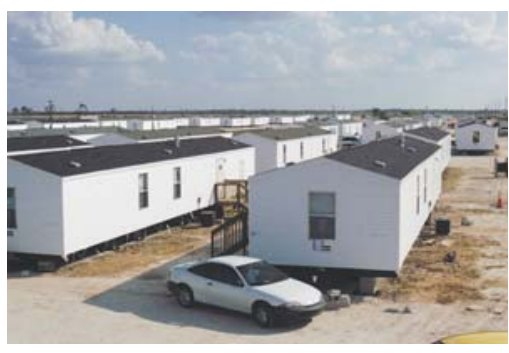

FEMA mobile homes being set up in Port Charlotte, Florida, to provide temporary housing for victims of Hurricane Charley (August 2004). Nearly a year after the storm, these trailers were still being used. (FEMA photo.) 


\section{A Review of Money Matters}

\section{Financial Impacts of Earthquakes}

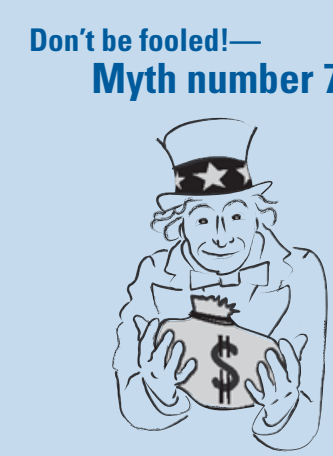

“I DON'T NEED TO WORRY ABOUT EARTHOUAKESTHE GOVERNMENT WILL SAVE ME!"

Many people wrongly believe that the U.S. Government will take care of all their financial needs if they suffer losses in an earthquake. The truth is that Federal disaster assistance is only available if the President formally declares a disaster. Even if you do get disaster assistance, it is usually a loan that you must repay, with interest, in addition to mortgages and other financial obligations you still owe, even on damaged property. If you don't qualify for loans, grants may be available to you. However, these are only designed to meet your most immediate needs, not to replace your losses (see pages 16 and 17).

For help in the first week after an earthquake - contact:

Your county office of emergency services

American Red Cross

http://www.redcross.org/services/disaster/ 1-866-GET-INFO (438-4636)

Govenor's Office of Emergency Services (OES) http://www.oes.ca.gov/

Federal Emergency Management Agency (FEMA) http://www.fema.gov/about/process/

Following a quake, disaster aid may not be immediately available, so you should plan ahead. If you have prepared a financial disaster recovery plan, you are more likely to recover successfully after a quake. Financial recovery planning resources are available from:

- Operation Hope Emergency Financial First Aid Kit http://www.ncua.gov/Publications/brochures/EmergencyFinancialFirstAidKit.pdf

- American Red Cross-Disaster Recovery: A Guide to Financial Issues (2003) http://www.redcross.org/services/disaster/beprepared/FinRecovery/

- Federal Emergency Management Agency (FEMA) http://www.fema.gov/about/process/

- Small Business Administration http://www.sba.gov/disaster_recov/index.html

\section{Your financial disaster recovery kit}

After a damaging earthquake, you will need copies of essential financial documents, as well as emergency cash. Keep these items together, current, and stored in a fire-proof document safe. Consider purchasing a home safe or renting a safe deposit box. Some essential items in your financial disaster recovery kit are:

- Birth certificates.

- Marriage license/divorce papers and child custody papers.

- Passports and driver's licenses.

- Social security cards.

- Naturalization papers and residency documents.

- Military/veteran's papers.

- Critical medical information.

- Cash, in the event ATM or bank services are disrupted.

- Certificates for stocks, bonds, and other investments.

- Bank statements.

- Credit card numbers.

- A list of phone numbers for financial institutions and credit card companies where you have accounts.
- Insurance policies.

- An inventory of your household possessions.

- Appraisals of valuable jewelry, art, antiques, and heirlooms.

- Home improvement records.

- A backup of critical files on your computer (also keep a copy at work).

- A list of names, phone numbers, and e-mail addresses of critical personal and business contacts.

- Deeds, titles, and other ownership records for property such as homes, autos, RVs, and boats.

- Powers of attorney, including health-care powers of attorney.

- Wills or trust documents. 


\section{Earthquake Information on the Web}

A

fter an earthquake, knowing more about what just happened can reduce fears and help you understand what to expect next. Online earthquake information products include:

\section{Location and magnitude of recent earthquakes}

Within 1 to 2 minutes of an earthquake, its location and magnitude are available at several Web sites, including

http://earthquake.usgs.gov/ and http://quake.usgs.gov/recenteqs/latest.htm.

\section{"ShakeMap"}

Within 5 to 10 minutes of most felt earthquakes (magnitude 3.5 and greater) in the Bay Area, a "ShakeMap" is posted on the Web. This map shows the range of shaking intensities across a region. Every quake has only a single magnitude, but it produces a range of shaking intensity values over the area in which it is felt.

ShakeMaps use data from seismic instruments to provide a rapid picture of where the strongest shaking occurred. These maps help to identify areas where a quake's impact is greatest and are used by emergency managers to speed disaster response. ShakeMaps are available at http://www.cisn.org/shakemap.html or http://earthquake.usgs.gov/shakemap/.

\section{"Did You Feel It?"-Tell us what you felt!}

Personal experiences of the effects of an earthquake are very valuable to scientists. When you have felt a quake, please report your observations by using a quick survey found on the U.S. Geological Survey "Did You Feel It?" Web site at http://pasadena.wr.usgs.gov/shake/ca/.

When you fill out this online survey, your observations of actual damage and shaking are combined with those of thousands of other people. The quake's shaking intensities, derived from these observations, are displayed by ZIP code on a "Community Internet Intensity Map."
Who monitors California's earthquakes?

Earthquake monitoring for California is done by the California Integrated Seismic Network (CISN), a partnership among the U.S. Geological Survey (USGS), University of California Berkeley, Caltech, the California Geological Survey, and the Governor's Office of Emergency Services. CISN is part of a USGS national seismic-monitoring program called the Advanced National Seismic System (ANSS).

For more information go to:

http://www.cisn.org/

http://www.anss.org/

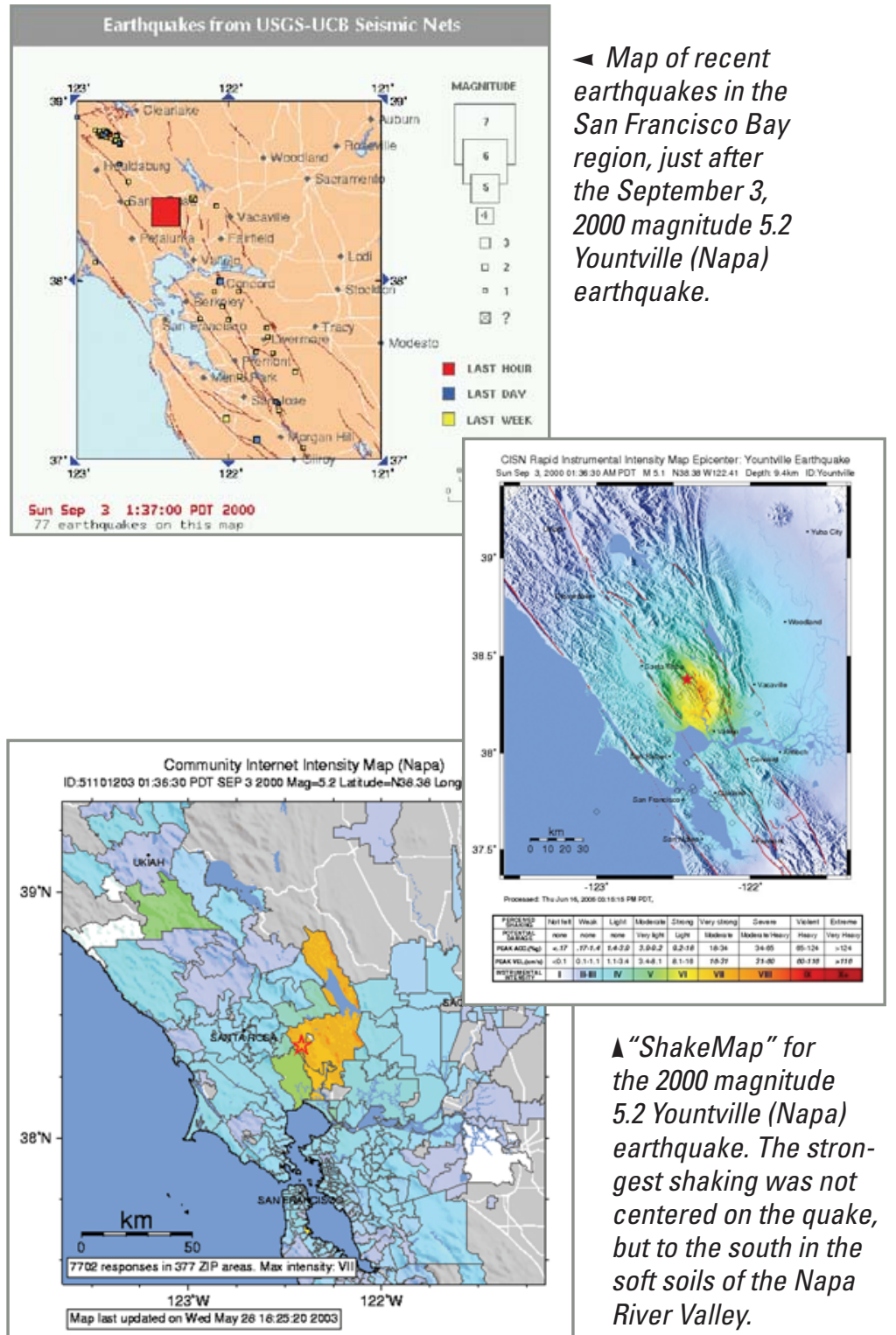
manitude 5.2 Yountville (Napa) earthquake.
- Map of recent
Community Internet Intensity Map ("Did You Feel It?") for the 2000 magnitude 5.2 Yountville (Napa) earthquake. More than 7,700 people reported their observations on this quake online. 


\section{Glossary}

Aftershock. Earthquakes that follow the largest shock of an earthquake sequence. They are smaller than the "mainshock" and can occur over a period of weeks, months, or years. In general, the larger the mainshock, the larger and more numerous the aftershocks and the longer they will continue.

Creep. Slow, more or less continuous movement occurring on some faults. Creep does not cause shaking.

Earthquake. Ground shaking caused by a sudden movement on a fault or by volcanic disturbance.

Epicenter. The point on the Earth's surface above the point at depth in the Earth's crust where an earthquake begins.

Fault. A fracture or crack along which two blocks of rock slide past one another. This movement may occur rapidly, in the form of an earthquake, or slowly, in the form of creep.

Foreshock. An earthquake that precedes the largest quake ("mainshock") of an earthquake sequence. Foreshocks may occur seconds to weeks before the mainshock.

Intensity. A measure of ground shaking describing the local severity of an earthquake in terms of its effects on the Earth's surface and on humans and their structures. The Modified Mercalli Intensity (MMI) scale, which uses Roman numerals, is one way scientists measure intensity.

Landslide. A mass movement of soil, mud, and (or) rock down a slope.

Liquefaction. The process that occurs when an earthquake shakes wet sandy soil until it behaves like a liquid, allowing sand to "boil up" to the surface, buildings to sink, or sloping ground to move.
Magnitude (M). A number that represents the size of an earthquake source, as determined from seismographic observations. The original earthquake magnitude scale was the Richter or "local" scale $\left(M_{L}\right)$, defined by Charles Richter in 1935, but it has limited range and applicability. Modern magnitude scales are based on the area of fault rupture times the amount of slip (seismic moment).The moment magnitude $\left(\mathrm{M}_{\mathrm{w}}\right)$ is the preferred magnitude scale, as it provides the most reliable estimate of the size of the largest quakes. For smaller quakes, $M_{L}$ and $M_{W}$ values are nearly the same. An increase of one unit of moment magnitude (for example, from 4.6 to 5.6) corresponds approximately to a 31.6-fold increase in energy released [by definition, a two-unit increase in magnitude — for example, from 4.7 to 6.7 -represents an increase in energy released of 1,000 times $(31.6 \times 31.6)]$. Quakes below magnitude 2.5 are not generally felt by humans.

Plate tectonics. The scientific theory that the Earth's outer shell is composed of several large, thin, relatively strong "plates" that move relative to one another. Movements on the faults that define plate boundaries produce most earthquakes.

Retrofit. Strengthening an existing structure to improve its resistance to the effects of earthquakes.

Rupture zone. The area of the Earth through which fault movement occurred during an earthquake. For large quakes, the section of the fault that ruptured may be several hundred miles in length. Ruptures may or may not extend to the ground surface.

Seismic hazard. The potential for damaging effects caused by earthquakes. The level of hazard depends on the magnitude of likely quakes, the distance from the fault that could cause quakes, and the type of ground materials at a site.
Seismic risk. The chance of injury, damage, or loss resulting from seismic hazards. There is no risk, even in a region of high seismic hazard, if there are no people or property that could be injured or damaged by a quake.

Soft story. A building story that has significantly less stiffness than the story above. Some buildings with parking at ground level (and thus fewer walls or columns) or an otherwise open ground story have this condition. The term is sometimes also applied to a story that has less strength than the one above, a condition that is more precisely termed a "weak story."

Strike-slip fault. A generally vertical fault along which the two sides move horizontally past each other. The most famous example is California's San Andreas Fault.

Subduction zone. A boundary along which one plate of the Earth's outer shell descends (subducts) at an angle beneath another. A subduction zone is usually marked by a deep trench on the sea floor. An example is the Cascadia Subduction Zone offshore of Washington, Oregon, and northern California. Most tsunamis are generated by subductionzone earthquakes.

Tsunami. A sea wave of local or distant origin that results from large sea-floor displacements associated with powerful earthquakes, major submarine landslides, or exploding volcanic islands. 
The online version of this publication can be found at: http://pubs.usgs.gov/gip/2005/15/

Multilingual versions of this publication series can be found at: http://earthquake.usgs.gov/regional/nca/prepare/

Why Should I Care?-The Bay Area Is Your Home (pages 4-11)

There are many faults in the Bay Area certain to produce large earthquakes in the future. All Bay Area communities are at risk from the damaging effects of quakes-strong shaking, landsliding, and liquefaction. Scientists estimate that there is more than a $60 \%$ chance of a damaging earthquake striking the region in the next 30 years.

\section{Why Should I Prepare? - Big Quakes Will Affect You (pages 12-17)}

The disastrous 1989 magnitude 6.9 Loma Prieta earthquake was not the "Big One"! If you do not prepare for the next big quake in the Bay Area, you and your family could be left without a home, food and water, medical supplies, and financial resources. START PREPARING NOW!

\section{What Should I Do? - Follow the Seven Steps to Earthquake Safety (pages 18-29)}

STEP 1. Identify potential hazards in your home and begin to fix them.

STEP 2. Create a disaster-preparedness plan.

STEP 3. Prepare disaster kits.

STEP 4. Identify your building's potential weaknesses and begin to fix them.

STEP 5. Protect yourself during earthquake shaking-DROP, COVER, AND HOLD ON.

STEP 6. After the quake, check for injuries and damage.

STEP 7. When safe, continue to follow your disaster-preparedness plan.

\section{ADDITIONAL PUBLICATIONS}

\section{Earthquakes}

by Bruce A. Bolt (ISBN: 0716756188)

Earthshaking Science: What We Know (and Don't Know) About Earthquakes by Susan Elizabeth Hough (ISBN: 0691050104)

Finding Fault in California: An Earthquake Tourist's Guide by Susan Elizabeth Hough (ISBN: 0878424954)

http://www.findingfault.com/
Furious Earth: The Science and Nature of Earthquakes, Volcanoes, and Tsunamis by Ellen J. Prager (ISBN: 0071351612)

Peace of Mind in Earthquake Country by Peter I. Yanev (ISBN: 0877017719)
Living with Earthquakes in California: $A$ Survivor's Guide by Robert S. Yeats (ISBN: 0870714937)

Homeowner's Guide to Earthquake Safety by the California Seismic

Safety Commission

(http://www.seismic.ca.gov/hog.htm)
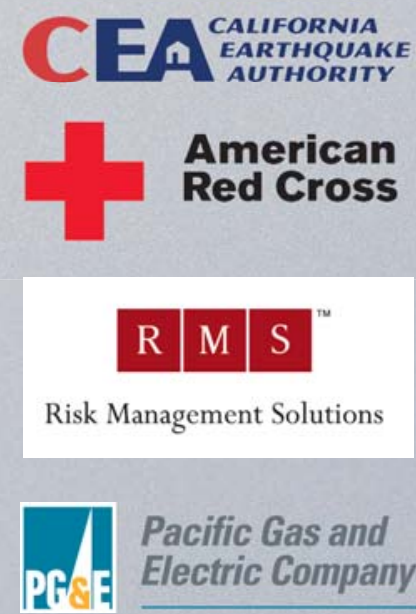

Pacific Gas and Electric Company
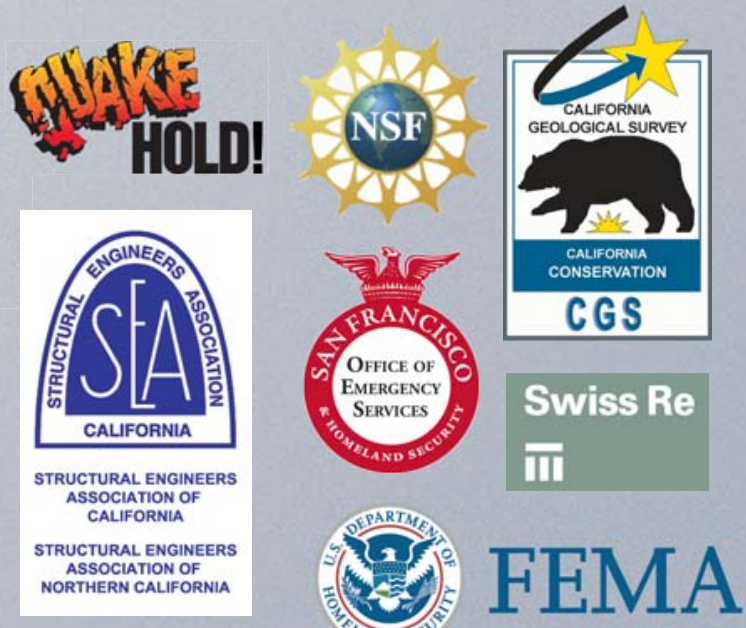
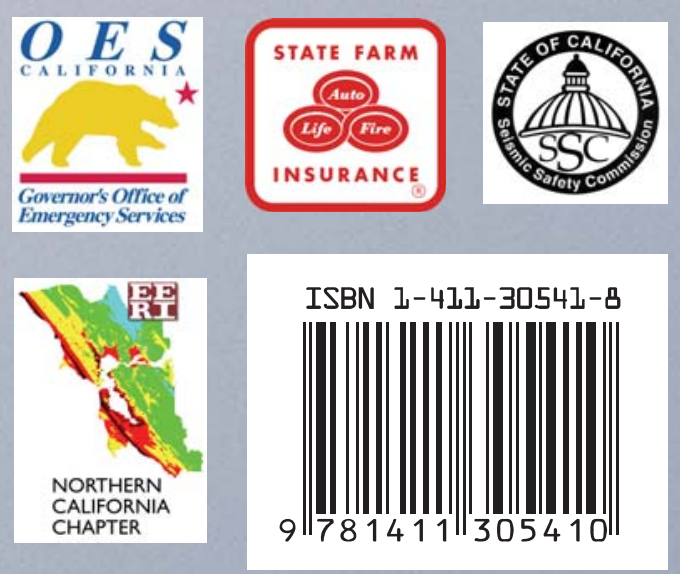